\title{
Crosstalk between the canonical NF-кB and Notch signaling pathways inhibits Ppary expression and promotes pancreatic cancer progression in mice
}

\author{
Eleni Maniati,1 Maud Bossard,", Natalie Cook, ${ }^{2}$ Juliana B. Candido,, ${ }^{1}$ Nia Emami-Shahri, ${ }^{1}$ \\ Sergei A. Nedospasov, ${ }^{3,4}$ Frances R. Balkwill, ${ }^{1}$ David A. Tuveson, ${ }^{2}$ and Thorsten Hagemann' \\ ${ }^{1}$ Centre for Cancer and Inflammation, Barts Cancer Institute, Queen Mary University of London, London, United Kingdom. \\ ${ }^{2}$ Cambridge Research Institute/CRUK, Cambridge, United Kingdom. ${ }^{3}$ Laboratory of Molecular Immunology, Engelhardt Institute of Molecular Biology, \\ Moscow, Russia. ${ }^{4}$ German Rheumatism Research Center, a Leibniz Institute, Berlin, Germany.
}

\begin{abstract}
The majority of human pancreatic cancers have activating mutations in the KRAS proto-oncogene. These mutations result in increased activity of the NF- $\kappa B$ pathway and the subsequent constitutive production of proinflammatory cytokines. Here, we show that inhibitor of $\kappa B$ kinase 2 (Ikk2), a component of the canonical NF- $\kappa B$ signaling pathway, synergizes with basal Notch signaling to upregulate transcription of primary Notch target genes, resulting in suppression of antiinflammatory protein expression and promotion of pancreatic carcinogenesis in mice. We found that in the Kras ${ }^{G 12 D} P d x 1$-cre mouse model of pancreatic cancer, genetic deletion of Ikk2 in initiated pre-malignant epithelial cells substantially delayed pancreatic oncogenesis and resulted in downregulation of the classical Notch target genes Hes 1 and Hey1. Tnf- $\alpha$ stimulated canonical NF- $\kappa$ B signaling and, in collaboration with basal Notch signals, induced optimal expression of Notch targets. Mechanistically, Tnf- $\alpha$ stimulation resulted in phosphorylation of histone $\mathrm{H} 3$ at the Hes 1 promoter, and this signal was lost with $I k k 2$ deletion. Hes1 suppresses expression of Pparg, which encodes the antiinflammatory nuclear receptor Ppar $\gamma$. Thus, crosstalk between Tnf- $\alpha / \mathrm{Ikk} 2$ and Notch sustains the intrinsic inflammatory profile of transformed cells. These findings reveal what we believe to be a novel interaction between oncogenic inflammation and a major cell fate pathway and show how these pathways can cooperate to promote cancer progression.
\end{abstract}

\section{Introduction}

Cancer-related inflammation has been shown to be critically linked with malignant disease - either by being the initiating, extrinsic cause or by supporting the intrinsic microenvironment during tumor progression (1). Most solid tumors are characterized by an intrinsic tumor-promoting inflammatory response (1). Activation of proto-oncogenes such as ras and/or inactivation of tumor suppressors orchestrates a proinflammatory transcriptional program and constitutive production of inflammatory cytokines and chemokines that shape a tumor-promoting microenvironment. Oncogenes and tumor suppressor genes are, however, difficult molecular targets in cancer therapy (2). In contrast, inflammatory cytokines and signaling pathways affected by the genetic changes occurring in malignant diseases are attractive druggable targets.

Activating mutations of the KRAS proto-oncogene are found in more than $90 \%$ of pancreatic ductal adenocarcinomas (PDACs), the most prevalent form of pancreatic cancer (3). Histological and molecular studies have demonstrated that disease progression occurs through a series of preinvasive lesions, pancreatic intraepithelial neoplasias (PanINs), that progress into invasive carcinoma (4). Mouse models with pancreas-specific activation of oncogenic Kras display the full spectrum of PanINs and recapitulate the features of human PDAC $(5,6)$. NF- $\kappa \mathrm{B}$, a major transcription fac-

Authorship note: Eleni Maniati and Maud Bossard contributed equally to this work. Conflict of interest: The authors have declared that no conflict of interest exists. Citation for this article: J Clin Invest. 2011;121(12):4685-4699. doi:10.1172/JCI45797. tor for inflammatory responses, is found activated in Kras-transformed epithelial cells $(7,8)$. NF- $\mathrm{\kappa B}$ activation is regulated through the inhibitor of $\kappa \mathrm{B}$ kinase (Ikk) complex, which consists of two catalytic subunits, Ikk1 and Ikk2 and the regulatory protein Ikk3 (or Nemo) (reviewed in ref. 9). During canonical NF-KB signaling, inflammatory stimuli including cytokines such as Tnf- $\alpha$ generate signals that converge at the Ikk complex, phosphorylating Ikk2, which in turn phosphorylates the inhibitory molecule inhibitor of $\kappa \mathrm{B}(\mathrm{I} \kappa \mathrm{B})$, resulting in its proteasomal degradation. This releases the $\mathrm{p} 65 / \mathrm{p} 50 \mathrm{NF}-\mathrm{\kappa B}$ heterodimer, allowing its nuclear translocation and promoter binding for inflammatory gene transcription. A series of studies has indicated a requirement of Ikk2 and p65 in both murine and human Kras-induced transformation of lung epithelial cells and in models of inflammation-induced carcinogenesis $(7,8,10,11)$. However, the implication of the pathway in pancreatic cancer has so far been unexplored.

Interestingly, in many types of cancer, including pancreatic cancer, the NF-кB and Notch pathways are activated (12-15). Classical activation of Notch signaling is triggered by ligation of Notch receptors and ligands. This leads to proteolytic cleavage of Notch and the release of the Notch intracellular domain (NICD). NICD subsequently translocates to the nucleus and binds to the DNA-binding protein Rbp-j. This interaction results in assembly of a transcriptional activation complex that drives the expression of Notch target genes (16). Among the best-characterized direct Notch target genes are the Hes and Hey families of transcriptional repressors. These genes are found to be upregulated in early PanINs 

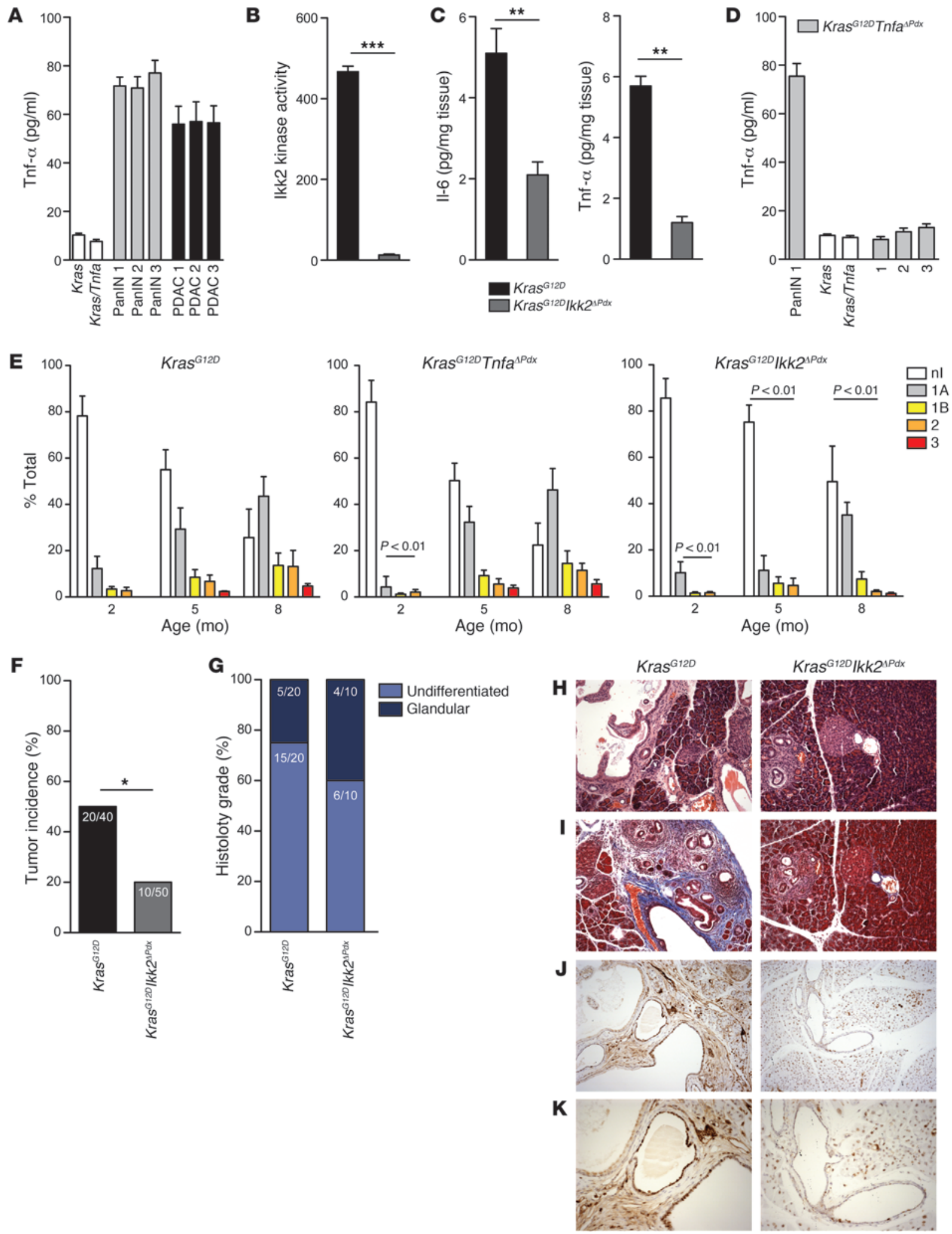


\section{Figure 1}

Genetic deletion of $l k k 2$ inhibits PanIN progression. (A) Tnf- $\alpha$ secretion by ductal cell lines derived from Kras ${ }^{G 12 D}$ PanIN- or PDAC-bearing mice measured by ELISA. Control cells were generated from Kras and Kras/Tnfa cre-negative pancreases. (B) Cellular lkk2 kinase activity in cell lines derived from $K \mathrm{ras}^{G 12 D}$ and $K \mathrm{ras}^{G 12 D} / k_{k} 2^{\Delta P d x}$ mice. (C) II-6 and Tnf- $\alpha$ secretion in pancreatic tissue of Kras ${ }^{G 12 D}$ and $K$ ras $^{G 12 D} / k_{k} 2^{\Delta P d x}$ mice. $n=6 ;{ }^{* *} P<0.01,{ }^{* * *} P<0.01$. (D) Tnf- $\alpha$ secretion by cell lines derived from Kras ${ }^{G 12 D}$ (PanIN 1) or Kras ${ }^{G 12 D} T n f a^{\Delta P d x}$ PanIN- or PDACbearing mice. Cre-negative Kras and Kras/Tnfa control cells were included. Data in $\mathbf{C}$ are shown as mean $+\mathrm{SD}$ of $n=6$ mice, and data in $\mathbf{A}, \mathbf{B}$, and $\mathbf{D}$ are mean + SD of triplicate experiments. (E) Quantification of the proportion of pancreas occupied by PanIN lesions. Frequency and grade of the lesions was quantified at 2, 5, and 8 months of age. Data are shown as mean $+\mathrm{SD} ; P<0.01$. nl, no lesion. $(\mathbf{F})$ Tumor incidence and $(\mathbf{G})$ histology grade in $K$ ras $^{G 12 D}$ and Kras ${ }^{G 12 D} / k_{k 2}{ }^{\Delta P d x}$ mice. ${ }^{*} P<0.05$. (H-K) Kras ${ }^{G 12 D}$ and Kras ${ }^{G 12 D} / k k 2^{\Delta P d x} 4$-month old pancreases stained with $(\mathbf{H})$ hematoxylin and eosin, (I) Masson's trichrome (blue, collagen; red, muscle fibers and cytoplasm; black, nuclei) and $(\mathbf{J}$ and $\mathbf{K})$ anti-PCNA. Original magnification, $\times 10(\mathbf{H}-\mathbf{J}), \times 20(\mathbf{K})$.

and throughout PDAC but not in normal pancreatic epithelium $(5,15)$. In the context of mutant Kras, Notch pathway activation has been shown to have a tumor-promoting role and has been implicated in mediating metaplasia of acinar to ductal epithelium, a critical process in pancreatic carcinogenesis (17-19).

In the present study we showed that genetic deletion of Ikk2

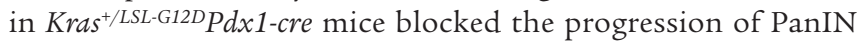
lesions. We further demonstrated that Tnf- $\alpha$ stimulation of initiated pre-malignant epithelial cells via Ikk2 engaged with canonical Notch signaling to upregulate the expression of primary Notch target genes. The crosstalk between NF-кB and Notch downregulated Ppary, a repressor of inflammatory gene expression and retained a constitutive production of proinflammatory mediators and cytokines by the transformed cells.

\section{Results}

Pancreas-specific deletion of Ikk2 blocks PanIN progression in Kras ${ }^{G 12 D}$ mice. Kras ${ }^{+/ L S L-G 12 D} P d x 1$-cre (abbreviated as Kras ${ }^{G 12 D}$ ) mice express an endogenous oncogenic Kras ${ }^{G 12 D}$ allele initially in pancreatic progenitors and later in the adult pancreas (5). We generated ductal epithelial cell lines from PanIN- and PDAC-bearing Kras $^{G 12 D}$ mice and identified constitutive secretion of Tnf- $\alpha$ (Figure 1A), similar to previous data indicating Tnf- $\alpha$ production by initiated premalignant ovarian epithelial cells (20). To determine the role of Ikk2/NF-кB signaling in formation and progression of PanINs, we generated $\mathrm{Kras}^{+/ L S L-G 12 D} I k k 2^{f l / f l} P d x 1$-cre $\left(\mathrm{Kras}^{G 12 D} I k k 2^{\Delta P d x}\right)$ mice. In parallel, we assessed the contribution of malignant cell-derived Tnf- $\alpha$ using $\mathrm{Kras}^{+/ L S L-G 12 D}$ Tnfa $^{f l / f l} \mathrm{Pdx1}$-cre (Kras $\left.{ }^{G 12 D} \mathrm{Tnfa}^{\Delta P d x}\right)$ mice.

The compound strains were generated by interbreeding C57BL/6 mice carrying floxed Ikk2 or Tnfa alleles with the $\mathrm{Kras}^{+/ L S L-G 12 D}$ and Pdx1-cre strains (Supplemental Figure 1A; supplemental material available online with this article; doi:10.1172/JCI45797DS1). No gross pathology was observed in the pancreas of Ikk2 $2^{\Delta P d x}$ or $T n f a^{\Delta P d x}$ mice (Supplemental Figure 1B). Activity of the Ikk complex was abolished in cells derived from $\operatorname{Kras}^{G 12 D} I k k 2^{\Delta P d x}$ mice, confirming excision of the Ikk2 locus (Figure 1B). Secretion of Tnf- $\alpha$ and Il- 6 in the pancreas was also significantly decreased $(P<0.01, n=6$, Figure 1C). Similarly, cell lines derived from PanIN- and PDACbearing $\operatorname{Kras}^{G 12 D} \operatorname{Tnfa}^{\Delta P d x}$ mice secreted minimal levels of Tnf- $\alpha$, confirming Tnfa inactivation (Figure 1D).
We assessed the development of PanIN lesions in cohorts $(n=12$ per time point) of $\operatorname{Kras}^{G 12 D}, \mathrm{Kras}^{G 12 D} I k k 2^{\Delta P d x}$, and $\operatorname{Kras}^{G 12 D} \operatorname{Tnfa} a^{\Delta P d x}$ mice at 2 , 5 , and 8 months of age. Histological assessment for the proportion of pancreas occupied by PanINs was carried out as previously described (4). Ikk2 deletion in $K r a s^{G 12 D} I k k 2^{\Delta P d x}$ mice resulted in a profound decrease in the frequency of high-grade PanINs (PanINs 2 and 3) at all time points $(P<0.01$; Figure $1 \mathrm{E})$. Only low-grade PanINs were present in 5-month-old Kras ${ }^{G 12 D} I k k 2^{\Delta P d x}$ mice, while approximately $80 \%$ of the pancreatic parenchyma retained normal exocrine tissue. Even at 8 months of age, formation of grade 2 and 3 lesions was minimal, and the frequency of grade 1 PanINs was lower compared with both $\operatorname{Kras}^{G 12 D}$ and $K r a s^{G 12 D} \operatorname{Tnfa}^{\Delta P d x}$ mice $(P<0.01$; Figure 1E).

Two-month-old $\operatorname{Kras}^{G 12 D} \mathrm{Tnfa}^{\Delta P d x}$ mice exhibited a significant reduction in early PanIN lesions $(P<0.01, n=12)$. However, by 5 months of age, PanINs had formed and progressed in a pattern similar to that in Kras $^{G 12 D}$ mice (Figure 1E). These results indicated that, in the context of mutant Kras, Ikk2 signaling was important for the development and progression of PanINs. Activation of the pathway by Tnf- $\alpha$ provided by the transformed epithelial cells was important early during the carcinogenic process. However, as the disease progressed, an influx of tumor-associated immune cells, primarily macrophages and neutrophils, compensated Tnf- $\alpha$ cytokine levels. To address the importance of the inflammatory infiltrate to compensate for the lack of inflammatory cytokines, we generated chimeras using $M x 1$-cre mice to target Tnf- $\alpha$ deletion in the leukocyte compartment (Supplemental Figure 2 , A-D). Infiltration of these cells was minimal in Kras ${ }^{G 12 D} I k k 2^{\Delta P d x}$ pancreases, indicating that Ikk2 inactivation impaired their capacity to attract other cell types (Supplemental Figure 2, A and B).

To assess whether Ikk2 depletion affected PDAC development, we followed cohorts of $50 \mathrm{Kras}^{G 12 D} I k \mathrm{~K}^{\Delta P d x}$ and $40 \mathrm{Kras}^{G 12 D}$ mice for nearly 2 years (Table 1 and Supplemental Table 1 ). Mice were sacrificed when they developed signs of distress. $20 \%$ of Kras $^{G 12 D} I k k 2^{\Delta P d x}$ mice had PDAC, while there was a 50\% tumor incidence in $\mathrm{Kras}^{\mathrm{G} 12 \mathrm{D}}$ mice (Figure $1 F$ ). Interestingly, deletion of Ikk2 changed the histopathological feature of the observed tumors, as shown by the ratio of undifferentiated to glandular morphology in these mice (Figure $1 \mathrm{G})$ at end point (Table 1 and Supplemental Table 1).

Further histological analyses of $K r a s^{G 12 D} I k k 2^{\Delta P d x}$ pancreases showed a profound delay in stromal reaction (Figure 1, H and I). Proliferation of acinar cells was assessed by PCNA expression. As shown in Figure 1, J and $\mathrm{K}$, there was a reduction in proliferating acinar cells in $\mathrm{Kras}^{G 12 D} I k k 2^{\Delta P d x}$ compared with $\mathrm{Kras}^{G 12 D}$ pancreases. No difference was noted in the levels of apoptosis, measured by cleaved caspase-3 staining (data not shown). Collectively, these data indicated that PanIN progression and development of PDAC were dependent on epithelial Ikk2 depletion.

Notch target genes Hes 1 and Hey 1 are downregulated in Kras ${ }^{G 12 D} I k k 2^{\Delta P d x}$ PanINs. The Notch pathway, normally quiescent in the adult pancreas, is found to be reactivated in pancreatic cancer throughout PanIN and PDAC development $(15,17,21)$. We assessed the regulation of Notch downstream targets as indicators of disease development (5). In accordance with previous studies, we found that the classical Notch target genes Hes 1 and Hey1 were expressed in $\mathrm{Kras}^{\mathrm{G} 12 \mathrm{D}}$ PanIN-bearing mice (5). However, there was a substantial decrease in their expression in age-matched $K_{r a s}^{G 12 D} \operatorname{Tnfa}^{\Delta P d x}$ and $\mathrm{Kras}^{G 12 D} I k k 2^{\Delta P d x}$ mice (Figure 2A). The pancreases of Kras ${ }^{G 12 D} I k k 2^{\Delta P d x}$ showed decreased expression of Igfr1, Vegf, and tenascin C, all Notch target genes, while expression of Myc and the AP-1 family transcription factor Batf was not altered (Figure 2A). Inactivation of Tnfa had little impact on the expression levels of these genes. Immunofluorescence analysis 
Table 1

Disease spectrum in $K r a s^{G 12 D} / k 2^{\Delta P d x}$ mice

\begin{tabular}{|c|c|c|c|c|c|c|c|c|c|c|}
\hline ID & Age (d) & PDAC & Histology & Liver & Lung & PD & Ascites & Skin & BO & Atrophy \\
\hline TH03-35 & 526 & $N$ & & $\mathrm{~N}$ & $\mathrm{~N}$ & $N$ & $\mathrm{~N}$ & $\mathrm{~N}$ & $\mathrm{~N}$ & Y \\
\hline TH03-58 & 599 & $\mathrm{~N}$ & & $\mathrm{~N}$ & $\mathrm{~N}$ & $\mathrm{~N}$ & $\mathrm{~N}$ & $\mathrm{~N}$ & $\mathrm{~N}$ & $Y$ \\
\hline TH03-59 & 517 & $\mathrm{~N}$ & & $\mathrm{~N}$ & $\mathrm{~N}$ & $\mathrm{~N}$ & $\mathrm{~N}$ & $\mathrm{~N}$ & $\mathrm{~N}$ & Y \\
\hline TH03-61 & 422 & Y & Glandular & Y & Y & Y & $\mathrm{N}$ & $\mathrm{N}$ & Y & \\
\hline TH03-66 & 501 & $\mathrm{~N}$ & & $\mathrm{~N}$ & $\mathrm{~N}$ & $\mathrm{~N}$ & $\mathrm{~N}$ & $\mathrm{~N}$ & $\mathrm{~N}$ & Y \\
\hline TH03-67 & 449 & N & & $\mathrm{N}$ & $\mathrm{N}$ & $\mathrm{N}$ & $\mathrm{N}$ & N & $\mathrm{N}$ & Y \\
\hline TH03-82 & 209 & $\mathrm{~N}$ & & $\mathrm{~N}$ & $\mathrm{~N}$ & $\mathrm{~N}$ & $\mathrm{~N}$ & Y & $\mathrm{N}$ & \\
\hline TH03-88 & 297 & $\mathrm{~N}$ & & $\mathrm{~N}$ & $\mathrm{~N}$ & $\mathrm{~N}$ & $\mathrm{~N}$ & Y & $\mathrm{N}$ & \\
\hline TH03-89 & 388 & $\mathrm{~N}$ & & $\mathrm{~N}$ & $\mathrm{~N}$ & $\mathrm{~N}$ & $\mathrm{~N}$ & $\mathrm{~N}$ & $\mathrm{~N}$ & $Y$ \\
\hline TH03-115 & 436 & $Y$ & Undifferentiated & $Y$ & Y & Y & $\mathrm{N}$ & $\mathrm{N}$ & $\mathrm{N}$ & \\
\hline TH03-131 & 587 & $\mathrm{~N}$ & & $\mathrm{~N}$ & $\mathrm{~N}$ & $\mathrm{~N}$ & $\mathrm{~N}$ & $\mathrm{~N}$ & $\mathrm{~N}$ & $Y$ \\
\hline TH03-136 & 555 & N & & $\mathrm{N}$ & $\mathrm{N}$ & $\mathrm{N}$ & $\mathrm{N}$ & N & $\mathrm{N}$ & $Y$ \\
\hline TH03-148 & 475 & $\mathrm{~N}$ & & $\mathrm{~N}$ & $\mathrm{~N}$ & $\mathrm{~N}$ & $\mathrm{~N}$ & $\mathrm{~N}$ & $\mathrm{~N}$ & $Y$ \\
\hline TH03-149 & 391 & $\mathrm{~N}$ & & $\mathrm{~N}$ & $\mathrm{~N}$ & $\mathrm{~N}$ & $\mathrm{~N}$ & $\mathrm{~N}$ & $\mathrm{~N}$ & Y \\
\hline TH03-167 & 155 & $\mathrm{~N}$ & & $\mathrm{~N}$ & $\mathrm{~N}$ & $\mathrm{~N}$ & $\mathrm{~N}$ & Y & $\mathrm{N}$ & \\
\hline TH03-177 & 422 & Y & Glandular & $Y$ & $\mathrm{~N}$ & $\mathrm{~N}$ & Y & $\mathrm{N}$ & $\mathrm{N}$ & \\
\hline TH03-181 & 448 & $\mathrm{~N}$ & & $\mathrm{~N}$ & $\mathrm{~N}$ & $\mathrm{~N}$ & $\mathrm{~N}$ & $\mathrm{~N}$ & $\mathrm{~N}$ & Y \\
\hline TH03-196 & 401 & $\mathrm{~N}$ & & $\mathrm{~N}$ & $\mathrm{~N}$ & $\mathrm{~N}$ & $\mathrm{~N}$ & $\mathrm{~N}$ & $\mathrm{~N}$ & Y \\
\hline TH03-197 & 412 & Y & Undifferentiated & $Y$ & $Y$ & $Y$ & $\mathrm{~N}$ & $\mathrm{~N}$ & $Y$ & \\
\hline TH03-206 & 389 & Y & Undifferentiated & $\mathrm{N}$ & $\mathrm{N}$ & $\mathrm{N}$ & $\mathrm{N}$ & $\mathrm{N}$ & $\mathrm{N}$ & \\
\hline TH03-207 & 455 & $\mathrm{~N}$ & & $\mathrm{~N}$ & $\mathrm{~N}$ & $\mathrm{~N}$ & $\mathrm{~N}$ & Y & $\mathrm{N}$ & \\
\hline TH03-213 & 438 & $\mathrm{~N}$ & & $\mathrm{~N}$ & $\mathrm{~N}$ & $\mathrm{~N}$ & $\mathrm{~N}$ & $\mathrm{~N}$ & $\mathrm{~N}$ & Y \\
\hline TH03-344 & 264 & $\mathrm{~N}$ & & $\mathrm{~N}$ & $\mathrm{~N}$ & $\mathrm{~N}$ & $\mathrm{~N}$ & Y & $\mathrm{N}$ & \\
\hline TH03-365 & 428 & $\mathrm{~N}$ & & N & $\mathrm{N}$ & $\mathrm{N}$ & $\mathrm{N}$ & $\mathrm{N}$ & $\mathrm{N}$ & Y \\
\hline TH03-374 & 417 & $\mathrm{~N}$ & & $\mathrm{~N}$ & $\mathrm{~N}$ & $\mathrm{~N}$ & $\mathrm{~N}$ & $\mathrm{~N}$ & $\mathrm{~N}$ & $Y$ \\
\hline TH03-384 & 409 & Y & Glandular & $\mathrm{N}$ & $\mathrm{N}$ & $\mathrm{N}$ & $\mathrm{N}$ & $\mathrm{N}$ & $\mathrm{N}$ & \\
\hline TH03-402 & 337 & $\mathrm{~N}$ & & $\mathrm{~N}$ & $\mathrm{~N}$ & $\mathrm{~N}$ & $\mathrm{~N}$ & $\mathrm{~N}$ & $\mathrm{~N}$ & Y \\
\hline TH03-404 & 316 & Y & Undifferentiated & $Y$ & $Y$ & Y & Y & Y & Y & \\
\hline TH03-405 & 406 & $\mathrm{~N}$ & & $\mathrm{~N}$ & $\mathrm{~N}$ & $\mathrm{~N}$ & $\mathrm{~N}$ & $\mathrm{~N}$ & $\mathrm{~N}$ & $Y$ \\
\hline TH03-416 & 472 & $\mathrm{~N}$ & & $\mathrm{~N}$ & $\mathrm{~N}$ & $\mathrm{~N}$ & $\mathrm{~N}$ & $\mathrm{~N}$ & $\mathrm{~N}$ & $Y$ \\
\hline TH03-425 & 515 & $\mathrm{~N}$ & & N & $\mathrm{N}$ & $\mathrm{N}$ & $\mathrm{N}$ & $\mathrm{N}$ & $\mathrm{N}$ & Y \\
\hline TH03-431 & 411 & $\mathrm{~N}$ & & $\mathrm{~N}$ & $\mathrm{~N}$ & $\mathrm{~N}$ & $\mathrm{~N}$ & $\mathrm{~N}$ & $\mathrm{~N}$ & Y \\
\hline TH03-452 & 509 & Y & Undifferentiated & Y & Y & $\mathrm{N}$ & Y & $\mathrm{N}$ & Y & \\
\hline ТH03-497 & 377 & $\mathrm{~N}$ & & $\mathrm{~N}$ & $\mathrm{~N}$ & $\mathrm{~N}$ & $\mathrm{~N}$ & $\mathrm{~N}$ & $\mathrm{~N}$ & Y \\
\hline TH03-499 & 482 & $Y$ & Undifferentiated & $\mathrm{N}$ & $Y$ & $Y$ & $\mathrm{~N}$ & $\mathrm{~N}$ & $Y$ & \\
\hline TH03-503 & 568 & $\mathrm{~N}$ & & $\mathrm{~N}$ & $\mathrm{~N}$ & $\mathrm{~N}$ & $\mathrm{~N}$ & $\mathrm{~N}$ & $\mathrm{~N}$ & Y \\
\hline TH03-509 & 263 & $\mathrm{~N}$ & & N & $\mathrm{N}$ & $\mathrm{N}$ & $\mathrm{N}$ & $Y$ & $\mathrm{~N}$ & \\
\hline TH03-515 & 174 & $\mathrm{~N}$ & & $\mathrm{~N}$ & $\mathrm{~N}$ & $\mathrm{~N}$ & $\mathrm{~N}$ & Y & $\mathrm{N}$ & \\
\hline TH03-518 & 248 & $\mathrm{~N}$ & & $\mathrm{~N}$ & $\mathrm{~N}$ & $\mathrm{~N}$ & $\mathrm{~N}$ & Y & $\mathrm{N}$ & \\
\hline TH03-522 & 315 & $\mathrm{~N}$ & & $\mathrm{~N}$ & $\mathrm{~N}$ & $\mathrm{~N}$ & $\mathrm{~N}$ & $\mathrm{~N}$ & $\mathrm{~N}$ & \\
\hline TH03-546 & 427 & $\mathrm{~N}$ & & $\mathrm{~N}$ & $\mathrm{~N}$ & $\mathrm{~N}$ & $\mathrm{~N}$ & $\mathrm{~N}$ & $\mathrm{~N}$ & Y \\
\hline TH03-551 & 482 & $\mathrm{~N}$ & & $\mathrm{~N}$ & $\mathrm{~N}$ & $\mathrm{~N}$ & $\mathrm{~N}$ & $\mathrm{~N}$ & $\mathrm{~N}$ & Y \\
\hline TH03-552 & 517 & $\mathrm{~N}$ & & $\mathrm{~N}$ & $\mathrm{~N}$ & $\mathrm{~N}$ & $\mathrm{~N}$ & $\mathrm{~N}$ & N & Y \\
\hline TH03-568 & 268 & $\mathrm{~N}$ & & $\mathrm{~N}$ & $\mathrm{~N}$ & $\mathrm{~N}$ & $\mathrm{~N}$ & $Y$ & $\mathrm{~N}$ & \\
\hline TH03-574 & 216 & $\mathrm{~N}$ & & $\mathrm{~N}$ & $\mathrm{~N}$ & $\mathrm{~N}$ & $\mathrm{~N}$ & Y & $\mathrm{N}$ & \\
\hline TH03-681 & 498 & $\mathrm{~N}$ & & $\mathrm{~N}$ & $\mathrm{~N}$ & $\mathrm{~N}$ & $\mathrm{~N}$ & $\mathrm{~N}$ & $\mathrm{~N}$ & $Y$ \\
\hline TH03-682 & 571 & $\mathrm{~N}$ & & $\mathrm{~N}$ & $\mathrm{~N}$ & $\mathrm{~N}$ & $\mathrm{~N}$ & $\mathrm{~N}$ & $\mathrm{~N}$ & Y \\
\hline TH03-693 & 501 & $\mathrm{~N}$ & & $\mathrm{~N}$ & $\mathrm{~N}$ & $\mathrm{~N}$ & $\mathrm{~N}$ & $\mathrm{~N}$ & $\mathrm{~N}$ & $Y$ \\
\hline TH03-699 & 585 & Y & Glandular & $\mathrm{N}$ & $\mathrm{N}$ & $\mathrm{N}$ & Y & $\mathrm{N}$ & Y & Y \\
\hline TH03-706 & 433 & $\mathrm{~N}$ & & $\mathrm{~N}$ & $\mathrm{~N}$ & $\mathrm{~N}$ & $\mathrm{~N}$ & Y & $\mathrm{N}$ & $\mathrm{N}$ \\
\hline Median & 427.5 & $20 \% Y$ & $\begin{array}{c}60 \% \text { undifferentiated, } \\
40 \% \text { glandular }\end{array}$ & $12 \%$ & $12 \%$ & $10 \%$ & $8 \%$ & $24 \%$ & $12 \%$ & $58 \%$ \\
\hline
\end{tabular}

PD, peritoneal disease; BO, biliary obstruction.

revealed Hes1-positive staining in PanIN lesions of 3-month-old $\operatorname{Kras}^{G 12 D}$ mice. Similar levels of Hes1 were found in $\operatorname{Kras}^{G 12 D} T n f a^{\Delta P d x}$ mice (Figure 2B). In contrast, Hes 1 protein was minimal in agematched Kras ${ }^{G 12 D} I k k 2^{\Delta P d x}$ animals (Figure $2 \mathrm{~B}$ ). These results indicated concurrent activity of the classical NF-кB and Notch pathways.
To further dissect the interaction of the Tnf- $\alpha / \mathrm{Ikk} 2$ and Notch signaling pathways, we examined the response of cell lines derived from $\operatorname{Kras}^{G 12 D}$, Kras ${ }^{G 12 D} T n f a^{\Delta P d x}$ and Kras ${ }^{G 12 D} I k k 2^{\Delta P d x}$ mice to recombinant Tnf- $\alpha(\mathrm{rTnf}-\alpha)$ stimulation in vitro. Basal Notch activity in $\operatorname{Kras}^{\mathrm{G} 12 D}$ cell lines was demonstrated by nuclear localization of 

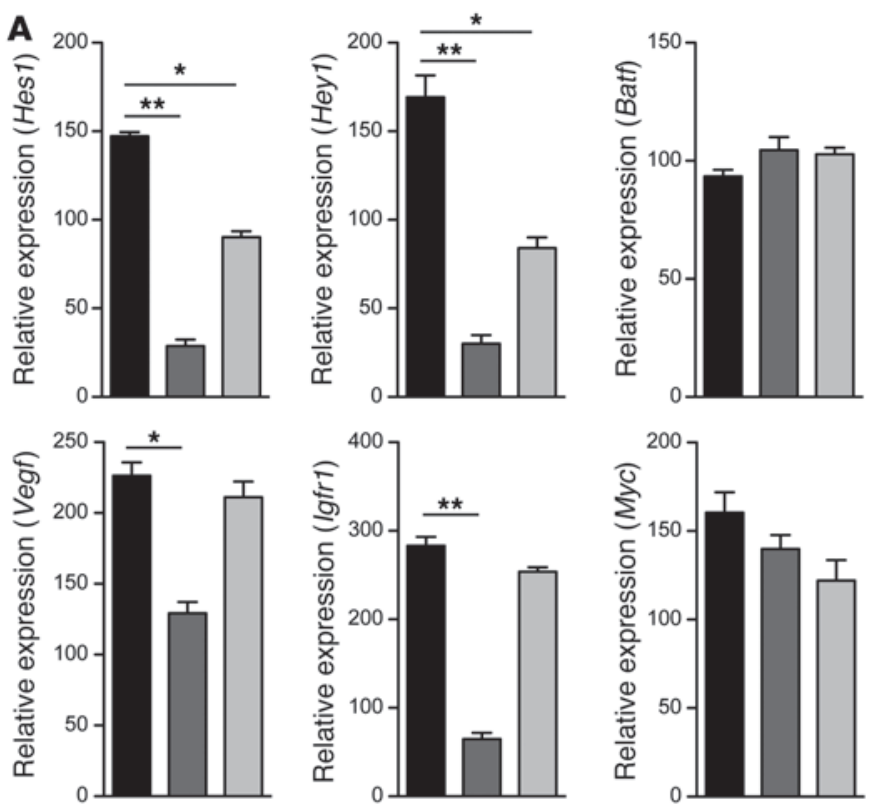

B

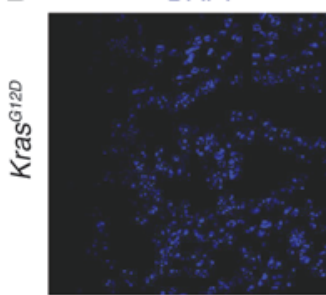

E-cadherin
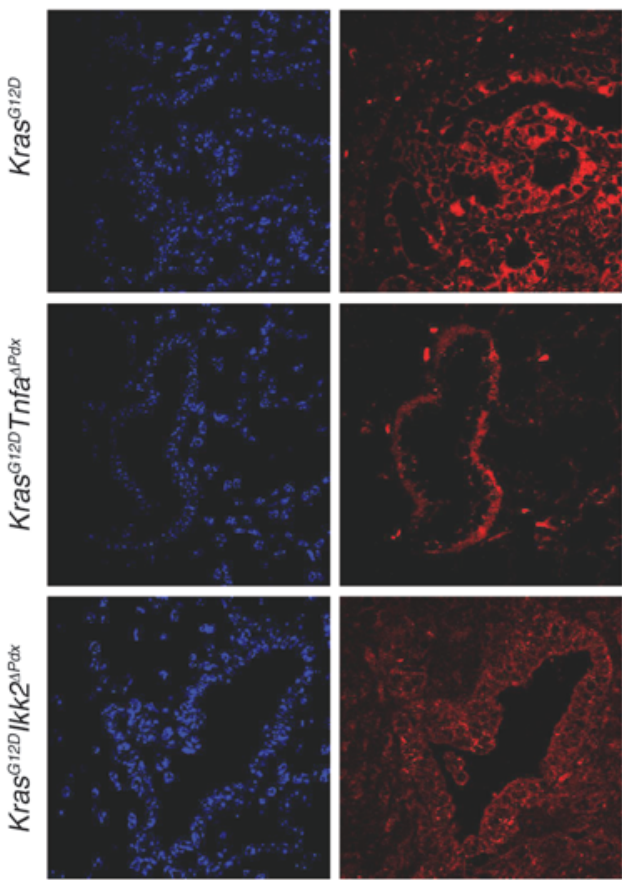

DAPI
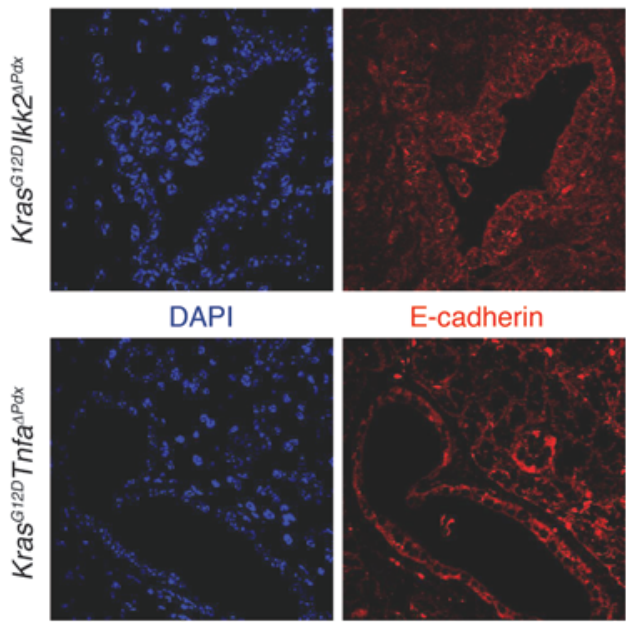

E-cadherin

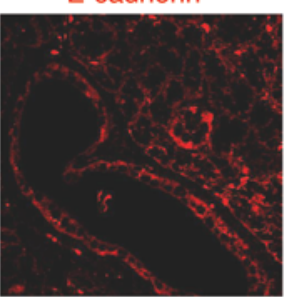

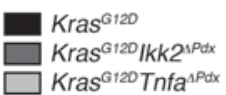

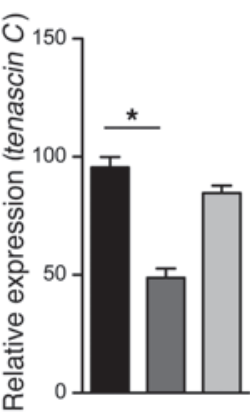

Hes1
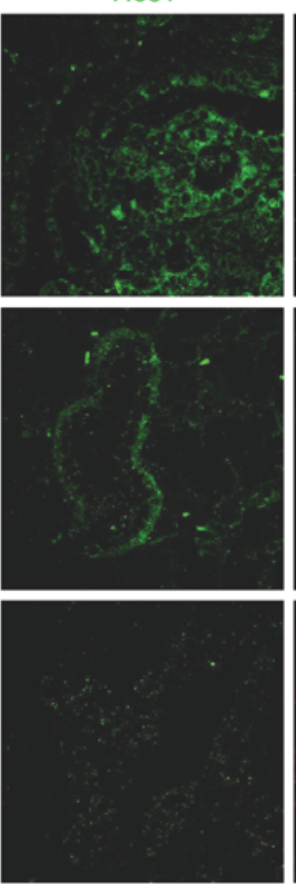

Control lg

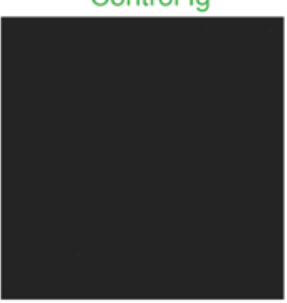

Merge
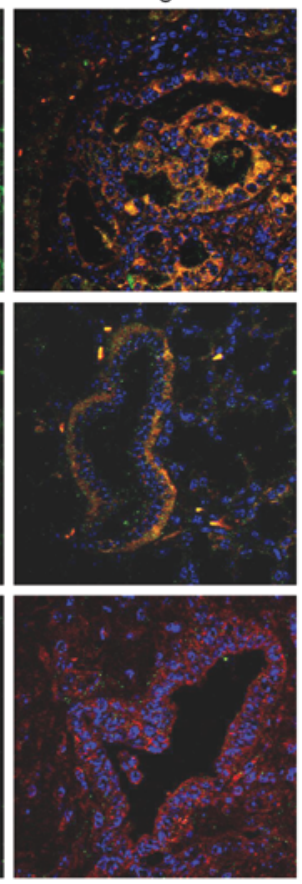

Merge

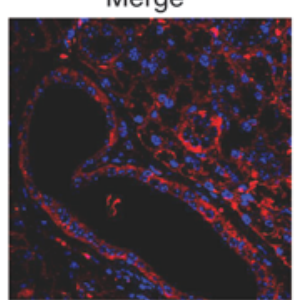

\section{Figure 2}

Molecular analysis of Notch and NF- $\mathrm{KB}$ target gene expression in Kras ${ }^{G 12 D}$ Tnfa ${ }^{\Delta P d x}$ and Kras G12DIkk2 ${ }^{\Delta P d x}$ pancreases. (A) Relative mRNA expression of Hes1, Hey1, Batf, Vegf, Igfr1, Myc, and tenascin $C$ in Kras ${ }^{G 12 D} T_{n f a}{ }^{\Delta P d x}$ and Kras G12DIkk2 ${ }^{\triangle P d x}$ 3-month PanIN-bearing pancreases was measured by real-time PCR. Data are shown as mean + SD; $n=6 .{ }^{\star} P<0.05,{ }^{\star}{ }^{\star} P<0.01$. The experiment was done in duplicate. (B) Immunofluorescence staining for Hes1 and $\mathrm{E}$-cadherin in PanIN-bearing pancreases from Kras ${ }^{G 12 D} \operatorname{Tnfa}^{\Delta P d x}$, Kras ${ }^{G 12 D} / k_{k} 2^{\Delta P d x}$, and Kras ${ }^{G 12 D}$ mice at 3 months of age. Original magnification, $\times 40$. Blue, DAPI; red, E-cadherin; green, Hes1.
Hes1 and low levels of cytoplasmic staining (Figure 3A). Stimulation with $r \operatorname{Tnf}-\alpha$ increased expression of both nuclear and cytoplasmic Hes1 protein (Figure 3A). The expression of Hes1, Hey1, as well as Batf, Vegf, Igfr1, Myc, and tenascin C was increased in Kras ${ }^{G 12 D}$ and
$\operatorname{Kras}^{G 12 D}{ }^{G n f} a^{\Delta P d x}$ cells after $r$ Tnf- $\alpha$ stimulation. In contrast, $r$ Tnf- $\alpha$ failed to upregulate expression of these genes in $\mathrm{Kras}^{G 12 D} I k k 2^{\Delta P d x}$ cells (Figure 3B and Supplemental Figure 3A). We next transiently transfected the cell lines with a Hes1 luciferase reporter construct and 

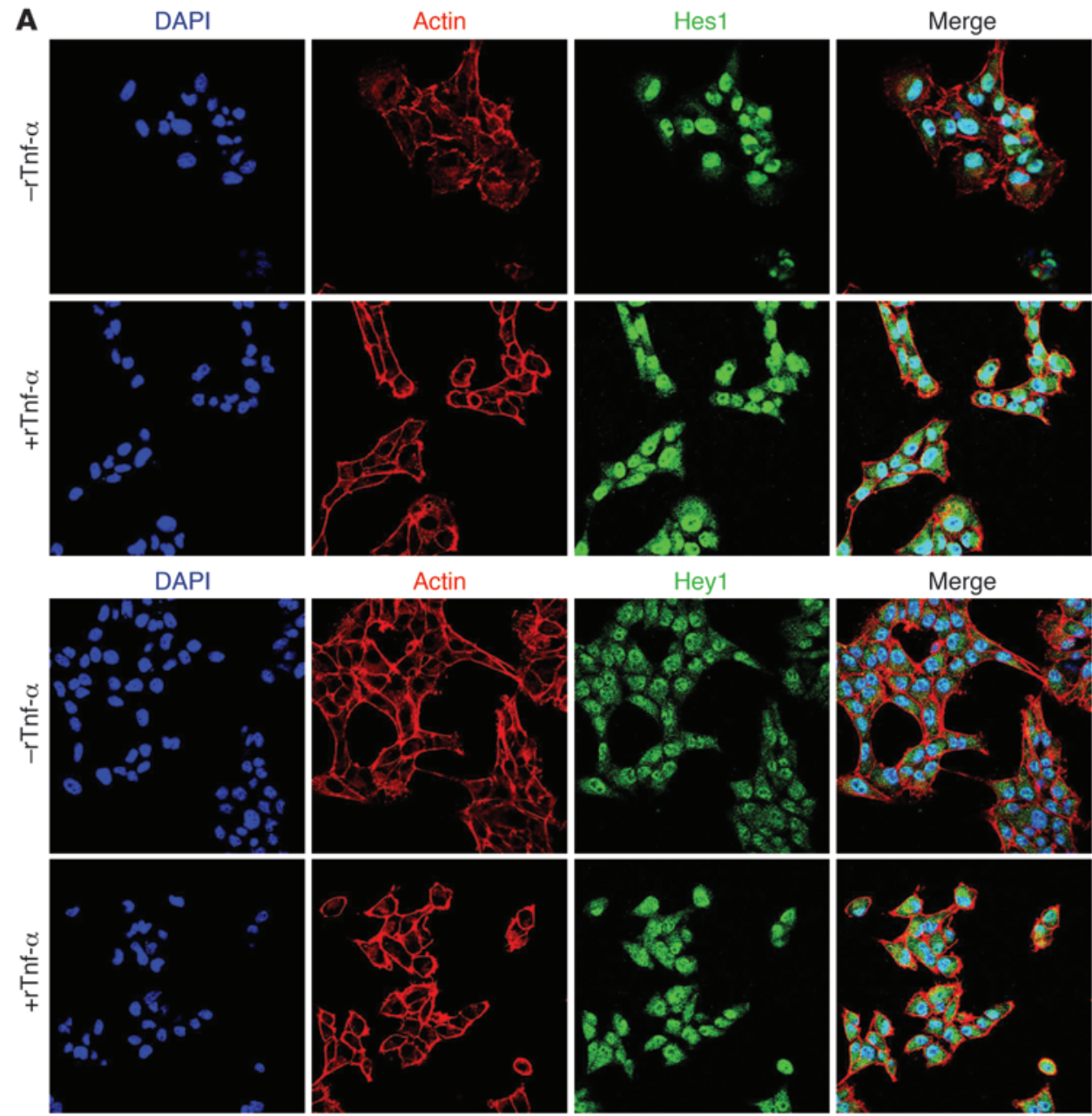

Actin

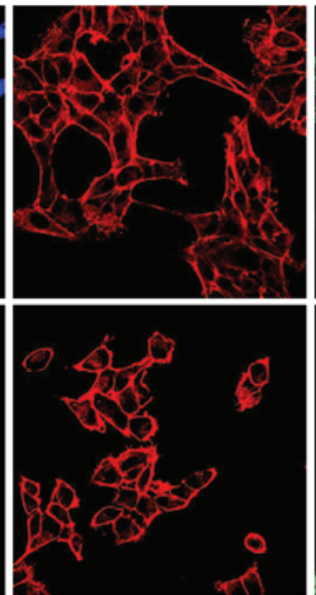

Actin
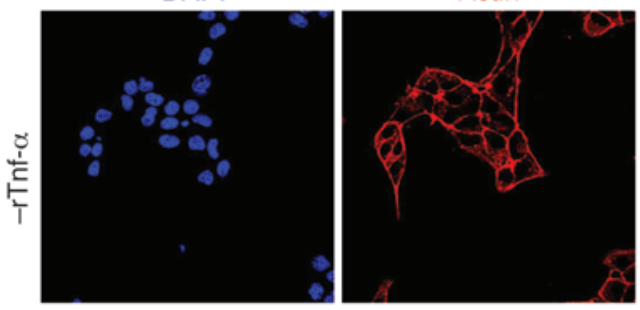

B

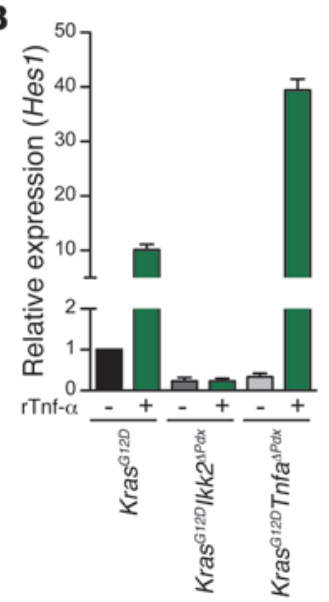

Hey1

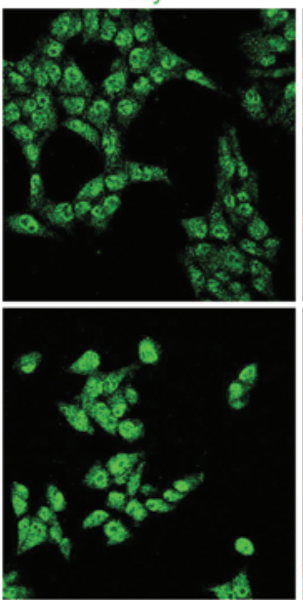

Control Ig

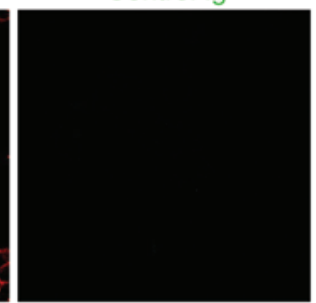

Merge

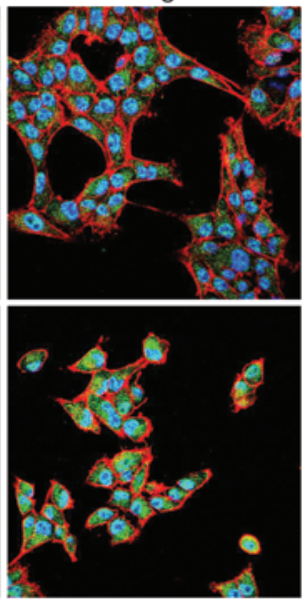

Merge

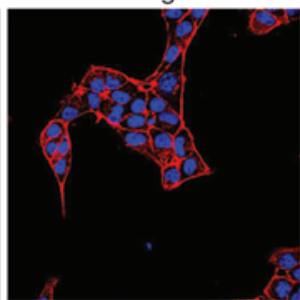

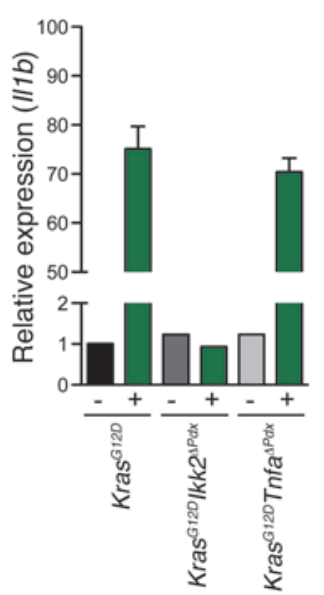

C

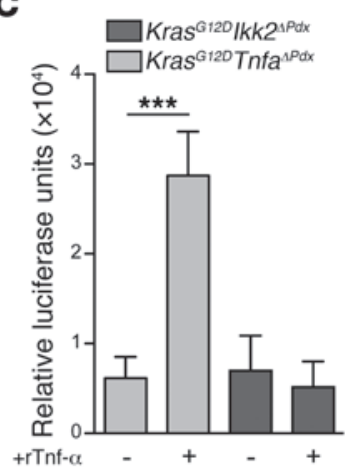

D

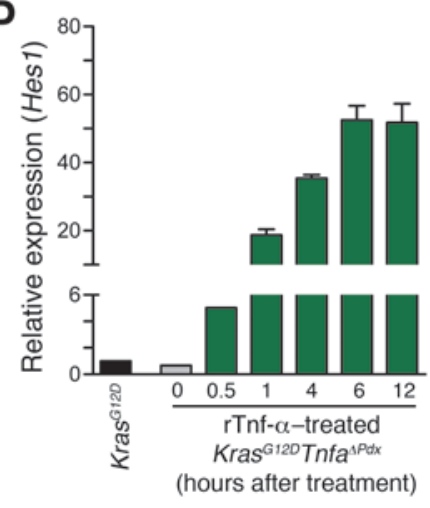

E

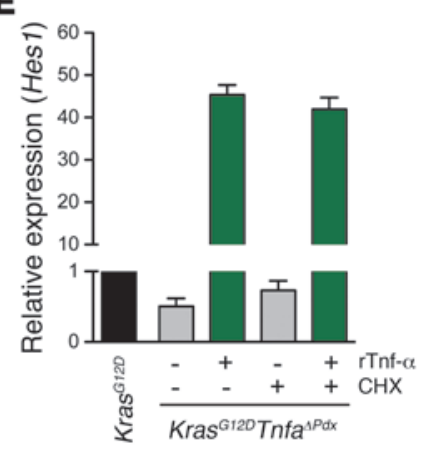




\section{Figure 3}

Tnf- $\alpha$-induced Notch and NF- $\kappa B$ target gene expression in PanIN cell lines. (A) Expression of Hes 1 and Hey 1 in $K_{r a s}{ }^{G 12 D}$ PanIN cell lines was examined by immunofluorescence staining; cells were left unstimulated or were stimulated with $10 \mathrm{ng} / \mathrm{ml} \mathrm{rTnf}-\alpha$ for 24 hours. Original magnification, $\times 40$. Blue, DAPI; red, actin; green, Hes1. One representative experiment of 3 performed is shown. (B) Relative mRNA expression of Hes 1 and $/ / 1 \mathrm{~b}$ in PanIN cell lines stimulated with $1 \mathrm{ng} / \mathrm{ml} \mathrm{rTnf- \alpha}$ for 6 hours. Relative expression was calculated by setting expression of untreated $K_{r a s^{G 12 D}}$ samples as 1. (C) Hes1 luciferase reporter assay

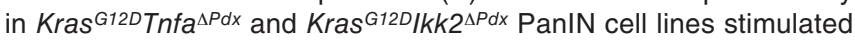
with $1 \mathrm{ng} / \mathrm{ml} \mathrm{rTnf}-\alpha$ for 6 hours. Results were normalized to firefly luciferase activity relative to internal control and are expressed as mean + SD from triplicate transfections. ${ }^{* \star *} P<0.01$. One representative experiment of 3 performed is shown. (D) Kinetic analysis of Hes1 mRNA expression in Kras ${ }^{G 12 D}$ Tnfa $^{\Delta P d x}$ PanIN cell lines stimulated with $1 \mathrm{ng} / \mathrm{ml} \mathrm{rTnf}-\alpha$. (E) Kras ${ }^{G 12 D} \operatorname{Tnfa}^{\Delta P d x}$ PanIN cells were treated with $1 \mathrm{ng} / \mathrm{ml} \mathrm{rTnf}-\alpha$ in the presence or absence of $15 \mu \mathrm{g} / \mathrm{ml}$ cycloheximide $(\mathrm{CHX})$. Expression of Hes 1 was quantified by real-time PCR. Relative expression was calculated by setting expression of untreated Kras ${ }^{G 12 D}$ samples as 1. (B, D, and E) Data are shown as mean + SD of triplicate determinants, and 1 representative experiment of 3 is shown.

stimulated them with $1 \mathrm{ng} / \mathrm{ml} \mathrm{rTnf}-\alpha$. This resulted in enhanced transcriptional activity of the Hes1 promoter in Kras ${ }^{G 12 D} \operatorname{Tnfa}^{\Delta P d x}$ but not in Kras ${ }^{G 12 D} I k k 2^{\Delta P d x}$ cells (Figure 3C). These results showed that in initiated pre-malignant epithelial cells Ikk2 signaling enhanced the expression of Notch target genes.

Activation of the NF- $\mathrm{KB}$ pathway is known to upregulate Notch receptors and ligands, both of which are found to be expressed on PanIN and PDAC cells $(17,22-26)$. However, an interaction downstream of the two pathways has not been described. We next assessed whether this enhanced expression of Notch target genes upon stimulation with rTnf- $\alpha$ was due to upregulation of Notch receptors and ligands, which would reinforce downstream signaling. We stimulated $K r a s^{G 12 D} T n f a^{\Delta P d x}$ cell lines with $\mathrm{rTnf}-\alpha$ over a full 12-hour time course and assessed mRNA expression of Hes 1 and Hey1. Upregulation of gene expression occurred within $30 \mathrm{~min}-$ utes and reached a plateau between 6 and 12 hours after treatment (Figure 3D and Supplemental Figure 3B). This rapid upregulation of Hes 1 and Hey 1 was independent of new protein synthesis and suggested a direct interaction between the pathways (Figure $3 \mathrm{E}$ and Supplemental Figure 3C).

Tnf- $\alpha$-induced Notch target gene expression requires canonical Notch signaling and Ikk2-mediated histone phosphorylation. We next sought to determine whether Tnf- $\alpha$-induced upregulation of Notch target genes required canonical Notch signaling. This is initiated by proteolytic cleavage of NICD following receptor-ligand interactions, mediated by the $\gamma$-secretase activity of a multiprotein complex (27). Pharmacological inhibition of $\gamma$-secretase using the synthetic inhibitor L685458 resulted in attenuation of Hes 1 and Hey1 expression in $\mathrm{rTnf}-\alpha$-stimulated $\operatorname{Kras}^{G 12 D} \operatorname{Tnfa}^{\Delta P d x}$ PanIN cell lines (Figure 4A). While expression of both these genes was sensitive to L685458, transcription levels of $I l 1 b, M m p 13$, and Cox2, all NF- $\mathrm{KB}$ targets, remained unaffected (Supplemental Figure 4). We maximally engaged Notch receptors by stimulating $\operatorname{Kras}^{G 12 D}$ cells with the classical Notch ligands Jagged-2 and Delta-like-1 (Dll1) and compared the levels of Hes 1 and Hey1 expression with those after treatment with rTnf- $\alpha$. rTnf- $\alpha$ induced higher Hes 1 and Hey1 levels than ligand-mediated Notch activation of the pathway (Figure 4B).
We further examined the requirement of Notch signaling for Tnf- $\alpha$-mediated upregulation of Hes 1 and Hey 1 using siRNA to knock down the expression of Rbpj, a nuclear transcription factor essential for Notch target gene expression. Transfection of $\operatorname{Kras}^{G 12 D} \operatorname{Tnfa}^{\Delta P d x}$ cell lines with Rbpj siRNA resulted in a 4-fold decrease in Hes 1 and Hey 1 transcripts, confirming the requirement of NICD-Rbp-j interaction for upregulation of target gene expression (Figure 4C and Supplemental Figure 5A). Expression of the NF-KB targets $I l 1 b$ and Cox2 remained unaffected in $R b p j$ knockdown cells (data not shown). Specific siRNA inhibition of Ikk2 also resulted in a downregulation of Hes1 and Hey1 expression following rTnf- $\alpha$ treatment (Figure 4D and Supplemental Figure $5 \mathrm{~B}$ ). This was consistent with our previous observation that $\mathrm{Kras}^{\mathrm{G} 12 D} I k k 2^{\triangle P d x}$ cell lines lost the capacity to upregulate Hes1 and Hey1 upon rTnf- $\alpha$ stimulation. Similarly, knockdown of Nemo blocked Hes1 and Hey1 expression (Supplemental Figure 5C), while knockdown of Ikk1 (Supplemental Figure 5D) had no effect on Hes1 or Hey1 expression.

Hes1 expression is not known to be regulated by NF-кB (16). To investigate the pathways downstream of Ikk2 that lead to Hes 1 activation, we examined phosphorylation of histone $\mathrm{H} 3$ at serine 10 , a histone modification that is induced by Ikk2 and is linked with recruitment of RNA polymerase II and transcriptional activation (28-30). We carried out ChIP and real-time PCR assays and showed that rTnf- $\alpha$ stimulation induced phosphorylation of histone $\mathrm{H} 3$ at serine 10 at the Hes 1 promoter (Figure 5). This inducible phosphorylation was abolished in Kras ${ }^{G 12 D} I k k 2^{\Delta P d x}$ cells (Figure 5). These results indicate a link between Tnf- $\alpha$-stimulated Ikk 2 signaling and the Hes 1 locus, whereby Tnf- $\alpha$ enhanced the transcriptional activity of a classical Notch target gene via Ikk 2 by inducing histone $\mathrm{H} 3$ phosphorylation.

Tnf- $\alpha$-induced crosstalk between NF- $\mathrm{\kappa} B$ and Notch pathways leads to Hes1-mediated Ppary inhibition. Hes1 is known to bind to the promoter region of the nuclear receptor Ppary and suppress its expression (31). Ppar $\gamma$ represses inflammatory gene expression induced by other classes of transcription factors including NF- $\kappa \mathrm{B}$. We observed higher Pparg mRNA expression in 2-month-old Kras $^{G 12 D}{ }^{T n f a} a^{\Delta P d x}$ and Kras ${ }^{G 12 D} I k k 2^{\Delta P d x}$ compared with Kras ${ }^{G 12 D}$ pancreases (Figure 6A). However, by 5 months of age, expression of Pparg in Kras ${ }^{G 12 D} T n f a^{\Delta P d x}$ was only marginally higher than in $\mathrm{Kras}^{G 12 D}$ mice. In contrast, it remained elevated in Kras ${ }^{G 12 D} I k k 2^{\Delta P d x}$ pancreases (Figure 6A). Moreover, after rTnf- $\alpha$ stimulation, Pparg mRNA in $\operatorname{Kras}^{G 12 D} \operatorname{Tnfa}^{\Delta P d x}$ cells decreased to levels similar to those in $\mathrm{Kras}^{\mathrm{G} 12 D}$ cells (Figure 6B). Binding of Hes1 to the Pparg promoter in $\operatorname{Kras}^{\mathrm{G} 12 D}$ cells was confirmed by ChIP (Figure 6C). These data indicated that Tnf- $\alpha$-induced Hes 1 upregulation in initiated premalignant cells resulted in Pparg suppression.

We further examined the interplay between Hes 1 and Pparg using Hes1-specific siRNA to knock down Hes1 expression in Kras ${ }^{G 12 D}$ PanIN cell lines. This resulted in robust upregulation of Pparg expression, which indicates Hes1-mediated inhibition of Pparg transcription (Figure 6D and Supplemental Figure 6, A and B). Similarly, Cebpa, a transcription factor whose expression requires Pparg, was also negatively regulated by Hes1 (Figure 6D and Supplemental Figure 6C).

Hes proteins suppress gene expression by a number of mechanisms that include binding to $\mathrm{N}$ boxes or suppressing E box-mediated transcription in promoters that contain tandem E boxes and Rbp-j sites (32-34). We investigated the mechanism by which Hes1 inhibits Pparg expression in our system by analyzing the effects of Hes 1 on 
A

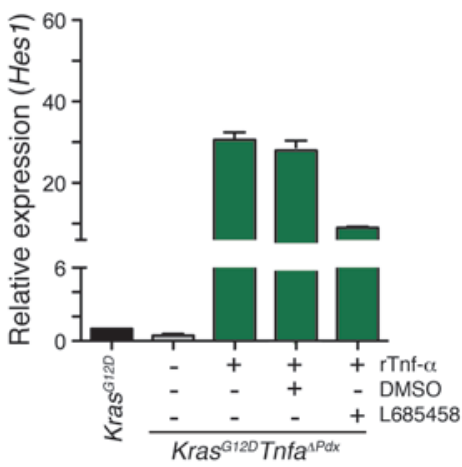

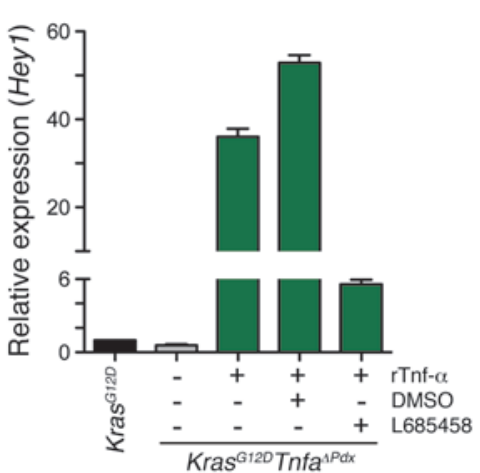

B

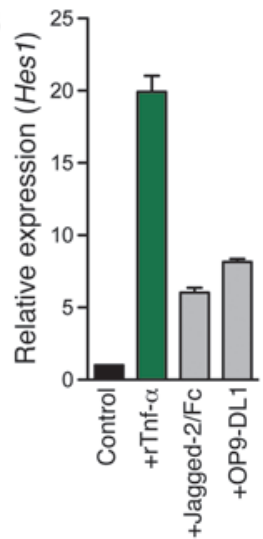

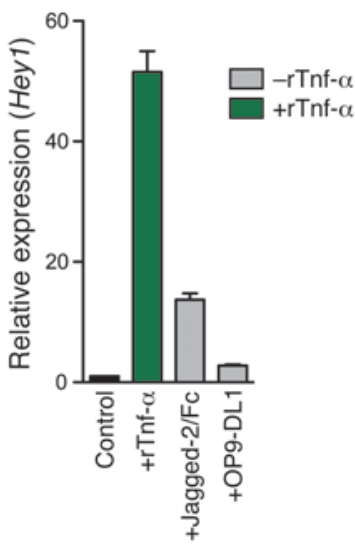

C
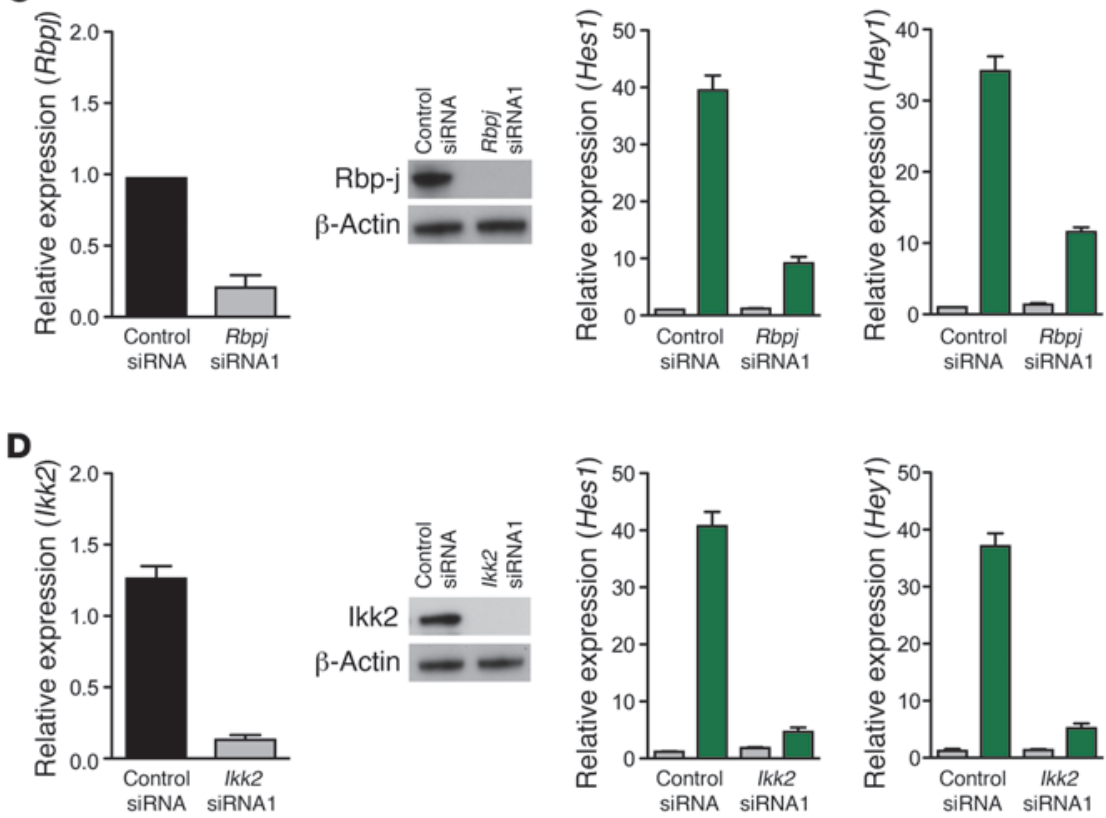

Figure 4

Tnf- $\alpha$-induced Notch target gene expression requires expression of Rbpj and Ikk2. (A) Inhibition of Hes1 and Hey1 mRNA expression in Tnf- $\alpha-$ induced Kras G12DTnfa ${ }^{\Delta P d x}$ PanIN cells treated with the $\gamma$-secretase inhibitor L685458 $(5 \mu \mathrm{M})$. Cells were stimulated with $1 \mathrm{ng} / \mathrm{ml} \mathrm{rTnf}-\alpha$. (B) Kras ${ }^{G 12 D} T_{n f a}{ }^{\Delta P d x}$ PanIN cells were treated with $\mathrm{rTnf}-\alpha, 20 \mu \mathrm{g} / \mathrm{ml}$ Jagged-2/Fc, or cocultured with OP9-DL1 cells. Tnf- $\alpha$ was more efficient in

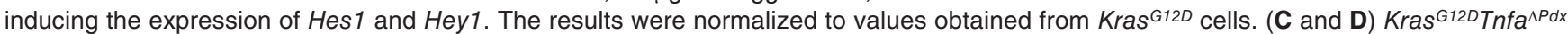
PanIN cell lines transfected with (C) $R b p j-$ or (D) Ikk2-specific siRNA. Forty-eight hours after transfection, cells were stimulated with $1 \mathrm{ng} / \mathrm{ml}$ rTnf- $\alpha$ for 6 hours, and expression of Hes 1 was quantified by real-time PCR. Nontargeting siRNA and/or unstimulated controls were included. Results were normalized to uninfected and unstimulated Kras ${ }^{G 12 D} \mathrm{Tnfa}^{\Delta P d x}$ cells. All data are shown as mean $+\mathrm{SD}$ of triplicate determinants and are representative of 3 independent experiments.

the activity of a Pparg promoter-driven reporter gene. We confirmed, in transient transfection assays, that Hes 1 suppressed expression of a Pparg promoter-driven reporter gene, in a dose-dependent manner (Figure 6E), through sequences from $-1,500$ to -160 that contain 6 E-box elements (31). A truncated E box sequence abrogated the ability of Hes1 to inhibit Pparg promoter activity (Figure 6F).

Pharmacological intervention in Notch and Ppary signaling modulates the inflammatory profile of malignant cells and inbibits PanIN growth. Pharmacological inhibition of NF- $\kappa \mathrm{B}$ or Notch signaling by antiTnf- $\alpha$, the NF-кB inhibitor Bay11-7082, or the $\gamma$-secretase inhibitor DAPT could block the expression of Hes 1 in PanIN-bearing 5-month-old mice. As shown in Figure 7, each of these approaches inhibited Hes 1 in PanIN-bearing pancreases and reduced Tnf- $\alpha$ cytokine levels in $\operatorname{Kras}^{G 12 D}$ cells $(P<0.01$; Figure 7, A-C).

We hypothesized that this interplay between NF-кB and Notch signaling and a coordinated downregulation of Pparg acted as a forward feedback loop that sustains expression of inflammatory cytokines and chemokines by the transformed cells. To address this hypothesis, we treated $\operatorname{Kras}^{G 12 D}$ mice with DAPT, a $\gamma$-secretase inhibitor. Cytokine arrays on whole pancreases of untreated and DAPT-treated mice revealed downregulation of proinflammatory cytokines and chemokines (Figure 7D). To further strengthen the impact of Notch signaling on the inflammatory state of the transformed cells, we used Kras ${ }^{G 12 D}$ mice carrying the Rosa26-LSL-Eyfp 
A
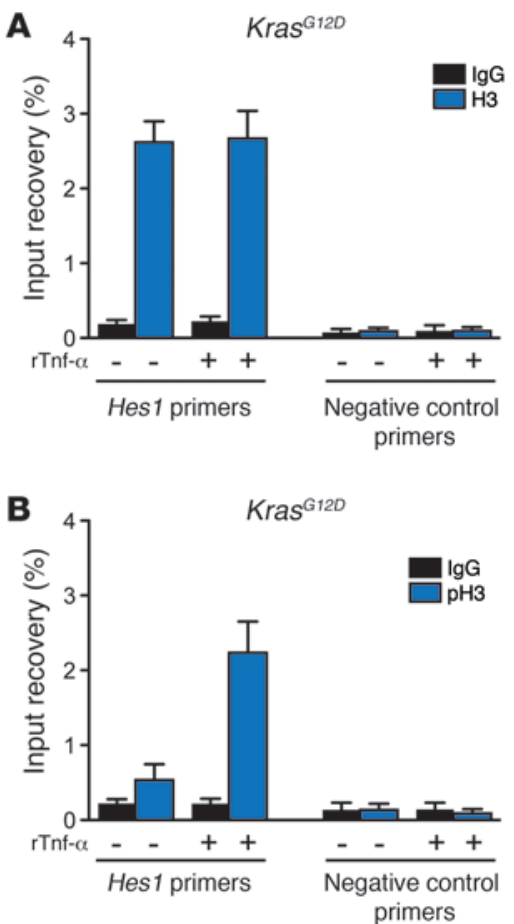
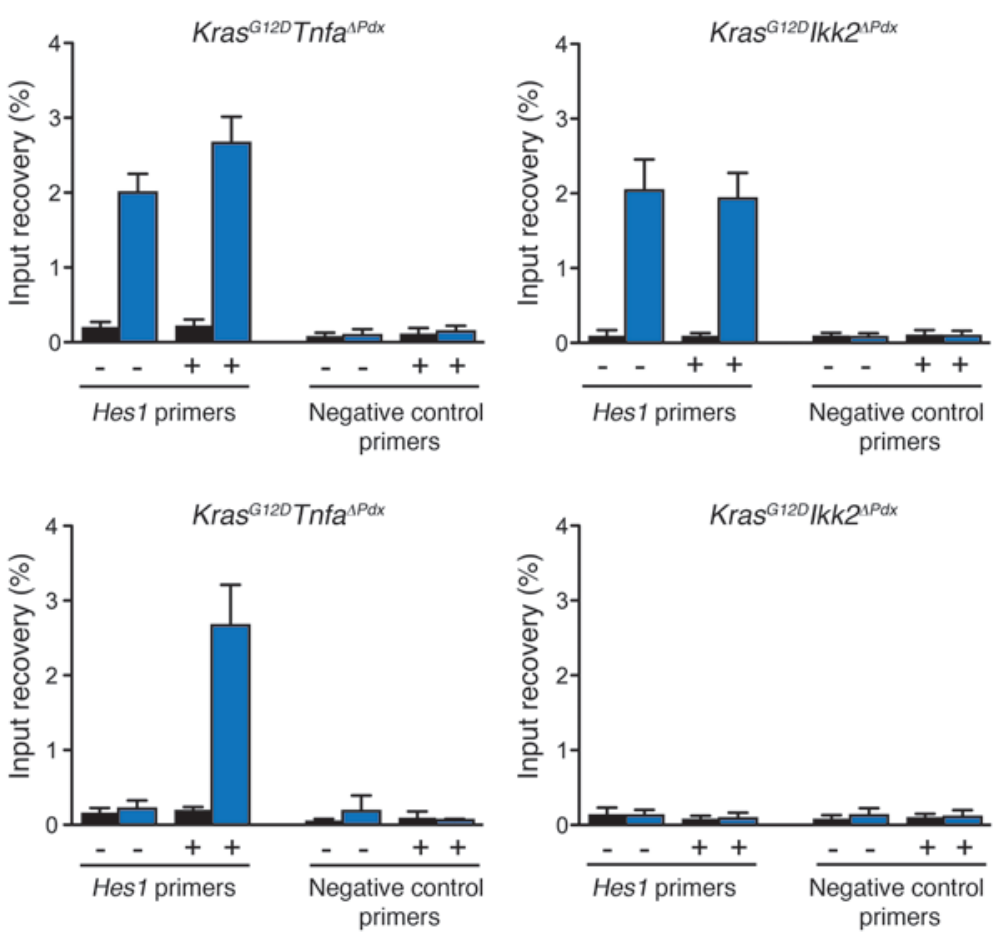

\section{Figure 5}

Tnf- $\alpha$-induced Notch target gene expression is dependent on Ikk2 and chromatin remodeling. ChIP was performed on rTnf- $\alpha$-treated $K r a s^{G 12 D}$, $K_{\text {Kas }}^{G 12 D T n f a}{ }^{\Delta P d x}$, and Kras ${ }^{G 12 D} / k_{k 2}{ }^{\Delta P d x}$ samples with anti-histone H3 (A) or anti-phospho-histone H3 at serine $10(\mathrm{pH} 3)(\mathbf{B})$. Rabbit IgG was used as control. Precipitated DNA was measured by real-time PCR using primers specific for Hes1. Results are shown as mean + SD of triplicate determinants and are representative of 3 independent experiments.

allele. In these mice, Eyfp expression was confined to the Kras ${ }^{G 12 D_{-}}$ expressing epithelial cell pool. Cohorts of $n=12$ mice were treated with DAPT or vehicle, and the Eyfp-positive cells were isolated by FACS. Analysis of the sorted cells showed significant downregulation of Tnfa $(P<0.05)$, Il6 $(P<0.001)$, and Il1b expression $(P<0.01)$ in the DAPT-treated group (Figure 7E).

We finally asked whether treatment with rosiglitazone, a Ppary agonist with antiinflammatory properties in vivo, would influence PanIN development in $\operatorname{Kras}^{G 12 D}$ mice $(35,36)$. Mice were treated with $3 \mathrm{mg} / \mathrm{kg} / \mathrm{d}$ rosiglitazone added to their daily diet, and cohorts of ras $^{G 12 D}$ mice were followed for nearly 2 years (Table 2). Progression of PanINs was significantly delayed in rosiglitazone-treated mice compared with the untreated controls $(P<0.01, n=12$, Figure $8 \mathrm{~A}$ ). Tumor incidence was 2 -fold lower (11 of 40) compared with that in untreated mice, greater than that observed in the Ikk2depleted Kras ${ }^{G 12 D} I k k 2^{\Delta P d x}$ animals (10 of 50) (Figure 8, B and C). Analysis of the macrophage infiltrate showed a reduction in the frequency of these cells in rosiglitazone-treated animals (Figure $8 D$ ). In total, these data suggest that modulation of tumor-associated inflammatory networks can inhibit PanIN progression and restrain stromal inflammatory components.

\section{Discussion}

The integrative interactions among proinflammatory cytokines, transcription factors, and oncogenic signaling pathways are currently the focus of extensive investigation. Here we demonstrated that in the context of Kras-driven pancreatic carcinogenesis, genetic inactivation of Ikk2 blocked the progression of PanIN lesions. Depletion of Ikk2 correlated with decreased expression of the clas- sical Notch target genes Hes1 and Hey1. Our further work showed that Tnf- $\alpha$-induced activation of the NF- $\kappa B$ pathway in initiated pre-malignant epithelial cells cooperated with basal Notch signals to enhance the expression of Notch target genes, in an Ikk2dependent manner. The interplay between Ikk2 and Notch, via the expression of Hes1, repressed the antiinflammatory nuclear receptor Ppary and created a forward feedback loop that retained the transformed cells in an inflammatory state.

Ikk2 is essential for canonical activation of NF- $\mathrm{KB}$ and has been shown to be required for carcinogenesis both in settings where $\mathrm{NF}-\mathrm{\kappa B}$ activation is driven by ras mutations and in inflammationinduced cancer models $(7,8,10,11)$. However, the role of the Ikk2/ $\mathrm{NF}-\kappa \mathrm{B}$ axis is context and cell type dependent; in certain settings, such as those observed in hepatocarcinogenesis, Ikk2 depletion results in tumor promotion (37). Our data demonstrated that in the context of Kras-driven pancreatic carcinogenesis, genetic deletion of Ikk2 blocked the progression of malignant epithelial cell lesions.

Activation of NF-KB is known to regulate a number of cellular processes, including a malignant cell-intrinsic network of inflammatory cytokines and chemokines (38). These act in an autocrine and paracrine manner both on the malignant cells and on the surrounding stroma and induce the activity of a number of oncogenic transcription factors, including Stat 3 and AP- 1 as well as NF- $\mathrm{B}$ itself $(10,11,20,39,40)$. With deletion of Ikk2 in initiated premalignant epithelial cells, an array of inflammatory cytokines and chemokines at the tumor site was significantly downregulated, and recruitment of macrophages and neutrophils was profoundly decreased (Supplemental Figure 2 and data not shown). Cellautonomous processes such as proliferation were also affected, 


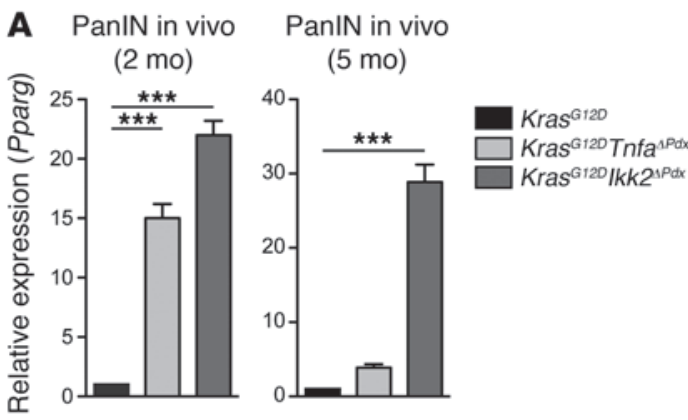

B
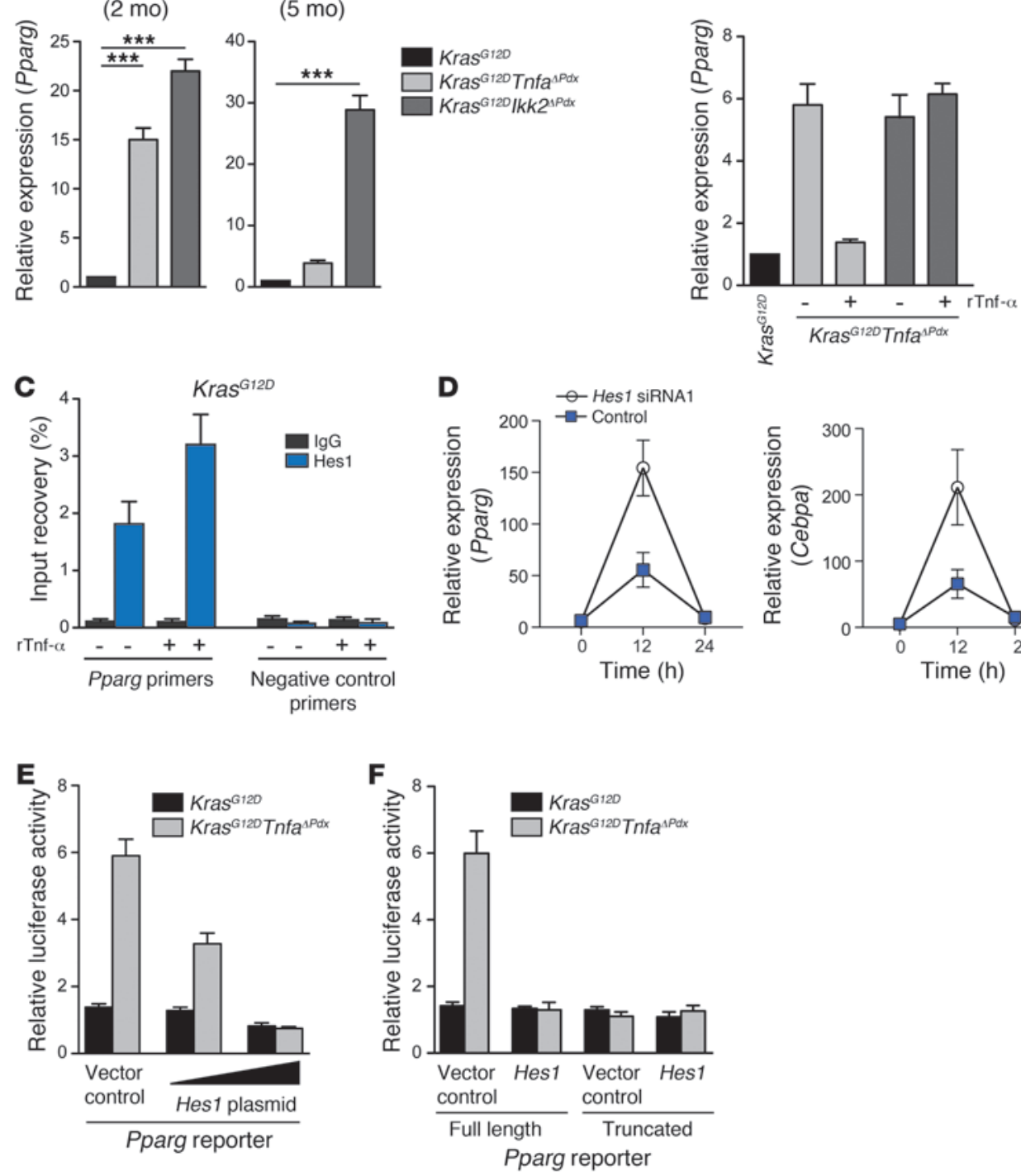

\section{Figure 6}

Tnf- $\alpha / N F-\kappa B$ and Notch crosstalk leads to Hes1-mediated Pparg inhibition. (A) Pparg mRNA expression in 2- and 5-month-old Kras ${ }^{G 12 D} \operatorname{Tnfa}^{\triangle P d x}$ and Kras ${ }^{G 12 D} / k k 2^{\Delta P d x}$ pancreases. Data were normalized to Kras ${ }^{G 12 D}$ pancreases. Data are shown as mean $+\mathrm{SD} ; n=6$. ${ }^{* * *} P<0.001$. The experiment was performed in duplicate. (B) Tnf- $\alpha$ stimulation $(1 \mathrm{ng} / \mathrm{ml})$ induced downregulation of Pparg in Kras $^{G 12 D}$ Tnfa $^{\Delta P d x}$ PanIN cell lines. (C) ChIP was performed on Kras ${ }^{G 12 D}$ cells using anti-Hes1 or a control IgG. Precipitated DNA was amplified by real-time PCR using primers specific for Pparg. (D) siRNA knockdown of Hes1 upregulated Pparg and Cebpa expression in Kras ${ }^{G 12 D}$ PanIN cells. (E) Kras ${ }^{G 12 D}$ and

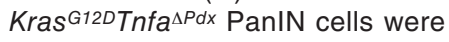
cotransfected in duplicate with a Pparg reporter construct containing 1,500 bases of the proximal Pparg promoter (full length) and a Hes1 expression plasmid or empty vector control. Twenty-four hours after transfection, cells were analyzed for luciferase activity. (F) Transfection of Kras ${ }^{G 12 D} T$ Tnfa ${ }^{\Delta P d x}$ PanIN cells as described in $\mathbf{E}$ with a full-length Pparg reporter construct or a construct with a truncated Hes1-binding sequence. All data are shown as mean + SD from duplicate transfections and are representative of 3 independent experiments. and downregulation of Notch target genes was observed. Notch signaling has oncogenic properties in pancreatic carcinogenesis; however, a link between this pathway and canonical NF-кB had not been previously appreciated (17-19).

Tnf- $\alpha$ is a major inflammatory cytokine that activates the NF- $\kappa$ B pathway and is regulated in its expression by NF- $\mathrm{BB}$. We demonstrated that Tnf- $\alpha$ stimulation of initiated pre-malignant epithelial cells resulted in upregulated expression of classical Notch targets. This occurred at the level of transcription by Ikk2-mediated phosphorylation of histone $\mathrm{H} 3$, a modification that is linked with transcriptional activation (28-30). Accordingly, Tnf- $\alpha$-mediated upregulation of Hes1 and Hey1 was independent of de novo protein synthesis but required canonical Notch signaling. Our data suggest that activation of NF- $\mathrm{KB}$ signaling can synergize with basal Notch signals to induce maximal expression of Notch target genes.

Conversely, Vilimas et al. have demonstrated that in $\mathrm{T}$ cell acute lymphoblastic leukemia, constitutively active Notch results in activation of the NF- $\kappa \mathrm{B}$ pathway (13). Work from the same group demonstrated that the Notch/Hes1 signaling sustained NF- $\mathrm{B}$ pathway activation by repressing the deubiquitinase CYLD, a negative Ikk complex regulator (41). In conjunction with our data, these studies indicate a bidirectional interaction between the NF-кB and Notch pathways that can result in bidirectional expression of target genes and enhanced malignant cell growth.

Within the tumor microenvironment, Tnf- $\alpha$ stems from two sources: the tumor-infiltrating immune cells and the malignant cells. In accordance with previous studies, we found an influx of inflammatory cells, predominantly macrophages and neutrophils, in $\mathrm{Kras}^{G 12 D}$ mice as disease progressed (42). These cells were a major source of the cytokine in aged mice. We also showed that Kras-induced PanIN and PDAC cells constitutively secreted low levels of Tnf- $\alpha$. Crosstalk between NF- $\mathrm{BB}$ and Notch signaling can therefore be fueled both by a constitutive autonomous activation of NF- $\mathrm{KB}$ signaling due to mutant Kras and by inflammatory cytokines provided by the immune cells. Our data suggested that early in the carcinogenic process, Tnf- $\alpha$ secreted by the malignant cells is critical for their growth, while at later stages, influx of immune cells constitutes the major source of the cytokine. 
Table 2

Disease spectrum in Kras ${ }^{G 12 D}$ mice treated with rosiglitazone

\begin{tabular}{|c|c|c|c|c|c|c|c|c|c|}
\hline ID & Age (d) & PDAC & Histology & Liver & Lung & PD & Ascites & Skin & BO \\
\hline CHS601-8 & 421 & $\mathrm{~N}$ & & $\mathrm{~N}$ & $\mathrm{~N}$ & $\mathrm{~N}$ & $\mathrm{~N}$ & $\mathrm{~N}$ & $\mathrm{~N}$ \\
\hline CHS601-15 & 438 & $\mathrm{~N}$ & & $\mathrm{~N}$ & $\mathrm{~N}$ & $\mathrm{~N}$ & $\mathrm{~N}$ & $\mathrm{~N}$ & $\mathrm{~N}$ \\
\hline CHS601-19 & 567 & $\mathrm{~N}$ & & $\mathrm{~N}$ & $\mathrm{~N}$ & $\mathrm{~N}$ & $\mathrm{~N}$ & $\mathrm{~N}$ & $\mathrm{~N}$ \\
\hline CHS601-21 & 558 & $\mathrm{Y}$ & Glandular & $\mathrm{N}$ & $\mathrm{N}$ & $Y$ & Y & $\mathrm{N}$ & Y \\
\hline CHS601-25 & 621 & $\mathrm{~N}$ & & $\mathrm{~N}$ & $\mathrm{~N}$ & $\mathrm{~N}$ & $\mathrm{~N}$ & $\mathrm{~N}$ & $\mathrm{~N}$ \\
\hline CHS601-27 & 521 & Y & Glandular & Y & $\mathrm{N}$ & $\mathrm{N}$ & Y & N & $Y$ \\
\hline CHS601-30 & 504 & Y & Glandular & $\mathrm{N}$ & $\mathrm{N}$ & Y & $\mathrm{N}$ & $\mathrm{N}$ & Y \\
\hline CHS601-31 & 486 & $\mathrm{~N}$ & & $\mathrm{~N}$ & $\mathrm{~N}$ & $\mathrm{~N}$ & $\mathrm{~N}$ & $\mathrm{~N}$ & $\mathrm{~N}$ \\
\hline CHS601-33 & 531 & $\mathrm{~N}$ & & $\mathrm{~N}$ & $\mathrm{~N}$ & $\mathrm{~N}$ & $\mathrm{~N}$ & $\mathrm{~N}$ & $\mathrm{~N}$ \\
\hline CHS601-46 & 367 & $\mathrm{~N}$ & & $\mathrm{~N}$ & $\mathrm{~N}$ & $\mathrm{~N}$ & $\mathrm{~N}$ & $\mathrm{~N}$ & $\mathrm{~N}$ \\
\hline CHS601-55 & 422 & $\mathrm{~N}$ & & $\mathrm{~N}$ & $\mathrm{~N}$ & $\mathrm{~N}$ & $\mathrm{~N}$ & $\mathrm{~N}$ & $\mathrm{~N}$ \\
\hline CHS601-57 & 394 & $Y$ & Undifferentiated & Y & $Y$ & N & $\mathrm{N}$ & N & $Y$ \\
\hline CHS601-67 & 357 & $Y$ & Glandular & Y & $\mathrm{N}$ & $\mathrm{N}$ & $\mathrm{N}$ & N & $\mathrm{N}$ \\
\hline CHS601-68 & 547 & $Y$ & Glandular & Y & $\mathrm{N}$ & $\mathrm{N}$ & Y & $\mathrm{N}$ & Y \\
\hline CHS601-69 & 555 & $\mathrm{~N}$ & & $\mathrm{~N}$ & $\mathrm{~N}$ & $\mathrm{~N}$ & $\mathrm{~N}$ & $\mathrm{~N}$ & $\mathrm{~N}$ \\
\hline CHS601-79 & 501 & $\mathrm{~N}$ & & $\mathrm{~N}$ & $\mathrm{~N}$ & $\mathrm{~N}$ & $\mathrm{~N}$ & N & $\mathrm{N}$ \\
\hline CHS601-80 & 408 & $\mathrm{~N}$ & & $\mathrm{~N}$ & $\mathrm{~N}$ & $\mathrm{~N}$ & $\mathrm{~N}$ & $\mathrm{~N}$ & $\mathrm{~N}$ \\
\hline CHS601-83 & 486 & $\mathrm{~N}$ & & $\mathrm{~N}$ & $\mathrm{~N}$ & $\mathrm{~N}$ & $\mathrm{~N}$ & N & $\mathrm{N}$ \\
\hline CHS601-84 & 433 & $\mathrm{~N}$ & & $\mathrm{~N}$ & $\mathrm{~N}$ & $\mathrm{~N}$ & $\mathrm{~N}$ & N & $\mathrm{N}$ \\
\hline CHS601-92 & 567 & $\mathrm{~N}$ & & $\mathrm{~N}$ & $\mathrm{~N}$ & $\mathrm{~N}$ & $\mathrm{~N}$ & $\mathrm{~N}$ & $\mathrm{~N}$ \\
\hline CHS601-96 & 555 & $\mathrm{~N}$ & & $\mathrm{~N}$ & $\mathrm{~N}$ & $\mathrm{~N}$ & $\mathrm{~N}$ & $\mathrm{~N}$ & $\mathrm{~N}$ \\
\hline CHS601-99 & 537 & $\mathrm{~N}$ & & $\mathrm{~N}$ & $\mathrm{~N}$ & $\mathrm{~N}$ & $\mathrm{~N}$ & $\mathrm{~N}$ & $\mathrm{~N}$ \\
\hline CHS601-108 & 521 & $\mathrm{~N}$ & & $\mathrm{~N}$ & $\mathrm{~N}$ & $\mathrm{~N}$ & $\mathrm{~N}$ & $\mathrm{~N}$ & $\mathrm{~N}$ \\
\hline CHS301-116 & 482 & $Y$ & Glandular & $\mathrm{N}$ & $\mathrm{N}$ & Y & Y & N & Y \\
\hline CHS601-127 & 444 & $\mathrm{~N}$ & & $\mathrm{~N}$ & $\mathrm{~N}$ & $\mathrm{~N}$ & $\mathrm{~N}$ & N & $\mathrm{N}$ \\
\hline CHS601-128 & 518 & $\mathrm{~N}$ & & $\mathrm{~N}$ & $\mathrm{~N}$ & $\mathrm{~N}$ & $\mathrm{~N}$ & N & $\mathrm{N}$ \\
\hline CHS601-142 & 525 & Y & Glandular & Y & $\mathrm{N}$ & $\mathrm{N}$ & $\mathrm{N}$ & $\mathrm{N}$ & Y \\
\hline CHS601-144 & 367 & $\mathrm{~N}$ & & $\mathrm{~N}$ & $\mathrm{~N}$ & $\mathrm{~N}$ & $\mathrm{~N}$ & $\mathrm{~N}$ & $\mathrm{~N}$ \\
\hline CHS601-161 & 418 & $\mathrm{~N}$ & & $\mathrm{~N}$ & $\mathrm{~N}$ & $\mathrm{~N}$ & $\mathrm{~N}$ & $\mathrm{~N}$ & $\mathrm{~N}$ \\
\hline CHS601-167 & 632 & $\mathrm{~N}$ & & $\mathrm{~N}$ & $\mathrm{~N}$ & $\mathrm{~N}$ & $\mathrm{~N}$ & $\mathrm{~N}$ & $\mathrm{~N}$ \\
\hline CHS601-170 & 555 & $Y$ & Undifferentiated & Y & $Y$ & N & $\mathrm{N}$ & $\mathrm{N}$ & $\mathrm{N}$ \\
\hline CHS601-177 & 407 & $\mathrm{~N}$ & & $\mathrm{~N}$ & $\mathrm{~N}$ & $\mathrm{~N}$ & $\mathrm{~N}$ & $\mathrm{~N}$ & $\mathrm{~N}$ \\
\hline CHS601-178 & 634 & $\mathrm{~N}$ & & $\mathrm{~N}$ & $\mathrm{~N}$ & N & $\mathrm{N}$ & $\mathrm{N}$ & $\mathrm{N}$ \\
\hline CHS601-185 & 524 & Y & Glandular & $\mathrm{N}$ & $\mathrm{N}$ & $\mathrm{N}$ & Y & $\mathrm{N}$ & Y \\
\hline CHS601-192 & 301 & $\mathrm{~N}$ & & $\mathrm{~N}$ & $\mathrm{~N}$ & $\mathrm{~N}$ & $\mathrm{~N}$ & $\mathrm{~N}$ & $\mathrm{~N}$ \\
\hline CHS601-197 & 287 & $\mathrm{~N}$ & & $\mathrm{~N}$ & $\mathrm{~N}$ & $\mathrm{~N}$ & $\mathrm{~N}$ & $\mathrm{~N}$ & $\mathrm{~N}$ \\
\hline CHS601-201 & 425 & $\mathrm{~N}$ & & $\mathrm{~N}$ & $\mathrm{~N}$ & N & $\mathrm{N}$ & $\mathrm{N}$ & $\mathrm{N}$ \\
\hline CHS601-222 & 486 & $\mathrm{~N}$ & & $\mathrm{~N}$ & $\mathrm{~N}$ & $\mathrm{~N}$ & $\mathrm{~N}$ & $\mathrm{~N}$ & $\mathrm{~N}$ \\
\hline CHS601-224 & 411 & Y & Glandular & Y & $\mathrm{N}$ & $\mathrm{N}$ & $\mathrm{N}$ & Y & $\mathrm{N}$ \\
\hline CHS601-229 & 518 & $\mathrm{~N}$ & & $\mathrm{~N}$ & $\mathrm{~N}$ & $\mathrm{~N}$ & $\mathrm{~N}$ & $\mathrm{~N}$ & $\mathrm{~N}$ \\
\hline Median & 493.5 & $27.5 \%$ & $\begin{array}{c}18 \% \text { undifferentiated, } \\
82 \% \text { glandular }\end{array}$ & $17.5 \%$ & $5 \%$ & $7.5 \%$ & $12.5 \%$ & $2.5 \%$ & $20 \%$ \\
\hline
\end{tabular}

Inflammation induced extrinsically by tissue damage (i.e., pancreatitis) or inflammation related to metabolic stress has been shown to accelerate PanIN development (43-45). The underlying mechanism is a deregulated regeneration process whereby constitutively active Notch permits PanIN formation. By identifying a direct link between NF-кB signaling and enhanced Notch activity, we provide evidence that a major proinflammatory and a developmental signaling pathway can cooperate in the context of mutant ras to promote carcinogenesis.

Repression of inflammatory genes by the nuclear receptor Ppary has been highlighted as an important mechanism by which cells can regulate inflammatory responses and homeostasis (46). Our findings demonstrated that a Tnf- $\alpha /$ Hes1-driven mechanism of Ppar $\gamma$ inhibition operates in initiated pre-malignant pancreatic epithelial cells. Hes1 suppressed Pparg expression by targeting E box elements in the promoter of the gene. We propose that the coordinated activity of NF-kB and Notch along with a suppression of antiinflammatory transcription factors such as Ppary leads to a sustained expression of inflammatory genes and transcription factors and a constitutive production of inflammatory mediators and chemokines by the transformed cells. Pharmacological inhibition of the Notch pathway in $\operatorname{Kras}^{G 12 D}$ mice with a $\gamma$-secretase inhibitor resulted in attenuation of inflammatory gene expression by the transformed cells and downregulation of cytokine production in the pancreas. It has also been shown to significantly attenuate the development of PanINs (21).

Synthetic Ppary ligands induce allosteric changes to the receptor and allow it to enter into a repression pathway (47). These agents are shown to have antiinflammatory activity in a variety of models of acute and chronic inflammation, as reviewed in ref. 35. By using rosiglitazone, a Ppary ligand of the thiazolidinedione class, to treat 

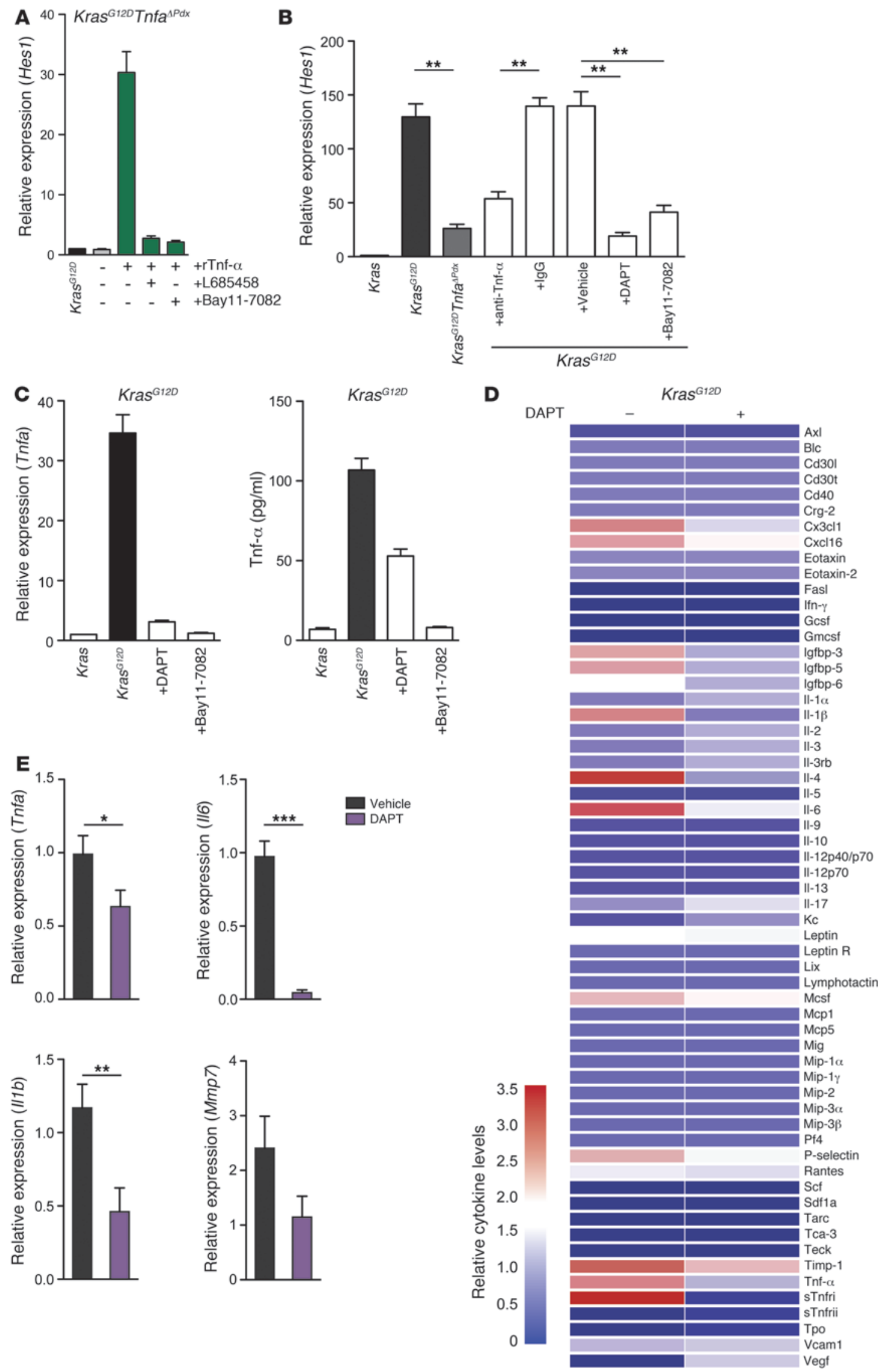


\section{Figure 7}

Inhibition of Notch/NF-kB signaling attenuates the inflammatory profile of malignant cells. (A) Kras ${ }^{G 12 D T n f a}{ }^{\Delta P d x}$ cells were stimulated with $1 \mathrm{ng} / \mathrm{ml} \mathrm{rTnf}-\alpha$ for 6 hours in the presence or absence of L685458 or Bay11-7082. Hes 1 mRNA expression was quantified by real-time PCR. Results were normalized to unstimulated $K$ ras $^{G 12 D}$ cells. Data are shown as mean $+\mathrm{SD}$ of triplicate determinants and are representative of 3 independent experiments. (B) Hes 1 mRNA expression in pancreases of 5-month-old untreated Kras ${ }^{G 12 D}$ and Kras ${ }^{G 12 D} / k_{k 2}{ }^{\Delta P d x}$ mice and of Kras ${ }^{G 12 D}$ mice treated with anti-Tnf- $\alpha$, control IgG, DAPT, Bay117082 , or the vehicle control. Results were normalized to Kras pancreases. Data are shown as mean $+\mathrm{SD} ; n=6 .{ }^{* \star} P<0.01$. The experiment was done in duplicate. (C) Kras ${ }^{G 12 D}$ PanIN cells were treated with DAPT or Bay11-7082. Tnfa mRNA expression and cytokine secretion are indicated. Data are shown as mean + SD of triplicate experiments and are representative of 3 independent experiments. (D) Cytokine and chemokine array on whole pancreases of DAPT or vehicle-treated 5 -month-old $\mathrm{Kras}^{\mathrm{G} 12 D}$ mice. The data are represented graphically as normalized signal intensity. (E) Tnfa, $/ / 6, \| 1 \mathrm{~b}$, and Mmp7 expression in FACS-sorted EYFP-positive Kras ${ }^{G 12 D}$ cells treated for 1 week with DAPT or vehicle. Data are shown as mean $+\mathrm{SD} ; n=12 .{ }^{*} P<0.05$, ${ }^{\star \star} P<0.01,{ }^{* \star} P<0.001$. Analysis of $M m p 7$ expression did not reveal statistical significance.

Kras ${ }^{G 12 D}$ mice, we demonstrated a marked decrease in the frequency of PanINs and their progression into invasive carcinoma. Nevertheless, Ppary has a wide range of effects on metabolism (48). Thiazolidinedione drugs are best characterized by their insulinsensitizing action and have been used in the treatment of diabetes. Notably, individuals with type 2 diabetes receiving metformin, a glucose-lowering drug, have a decreased risk of developing pancreatic cancer $(49,50)$.

Our findings and an increasing body of studies highlight the requirement for inflammatory signaling pathways in the development of pancreatic cancer and reveal key molecular targets to assist current treatments.

\section{Methods}

Mouse strains. Kras ${ }^{+/ L S L-G 12 D}, P d x 1$-cre (5), Tnfalffl (51), and Ikk2 $2^{f l / f l}$ strains (52) were interbred to obtain $\mathrm{Kras}^{G 12 D}, \mathrm{Kras}^{G 12 D} \mathrm{Tnfa} a^{\Delta P d x}$, and Kras ${ }^{G 12 D} I k k 2^{\Delta P d x}$ triple mutant mice on a mixed 129/SvJaa/C57BL/6 background (see Supplement Figure 1 for the breeding plan). Ikk $2^{f / f l}$ mice were a gift from Toby Lawrence (Inflammation Biology Group, Centre d'Immunologie de Marseille-Luminy, CNRS-INSERM-Université de la Méditerranée, Marseille, France). Mx1-cre mice were obtained from The Jackson Laboratory (53) and crossed to Tnfallfl mice. The mice were genotyped at weaning by a commercial vendor (Transnetyx). Six-week-old $K r a s^{G 12 D}$ and $K r a s^{G 12 D} \operatorname{Tnfa}^{\Delta P d x}$ female mice were lethally irradiated and underwent transplantation with bone marrow of female $T n f^{f l / f l}$ or $T n f a^{\prime l / f l} M x 1$-cre mice $(n=10$ each group). Twomonth old mice were injected 3 times with $5 \mu \mathrm{g} / \mathrm{g}$ body weight poly(I:C) to delete Tnfa. Deletion was examined by Tnf- $\alpha$ ELISA of peripheral leukocytes upon ex vivo LPS stimulation. For in vivo experiments, we used rosiglitazone (Cayman Chemical) incorporated into standard rodent chow (3 mg/kg/d; 8 weeks); the Notch antagonist $N$-[ $N$-(3,5-difluorophenacetyl)-L-alanyl]-S-phenylglycine $t$-butyl ester (DAPT $/ \gamma$-secretase inhibitor IX, Calbiochem) at $100 \mathrm{mg} / \mathrm{kg} / \mathrm{d}$ i.p.; L685458 (Sigma-Aldrich) and Bay117082 (Alexis) at $10 \mathrm{mg} / \mathrm{kg} / \mathrm{d}$ i.p. or vehicle; anti-murine Tnf- $\alpha$ (R\&D Systems) at $10 \mathrm{mg} / \mathrm{kg} / \mathrm{d}$ or respective IgG control antibody (R\&D Systems). Five-month-old mice were treated for 1 week.

Cell lines and reagents. Primary pancreatic ductal cell lines were derived from $\mathrm{Kras}^{G 12 D}, \mathrm{Kras}^{G 12 D} \operatorname{Tnfa}^{\Delta P d x}$, and $\mathrm{Kras}^{G 12 D} I k k 2^{\Delta P d x}$ mice as previously described (54). PanIN cell lines were derived from PanIN lesions with no invasive cancer present within the pancreas of the mouse. OP9-DL1 cells, a bone marrow-derived stromal cell line that ectopically expresses the Notch ligand Dll1 (55), were cocultured with $K r a s^{G 12 D} T n f a^{\Delta P d x}$ pancreatic ductal cells. Cycloheximide and L685458 were purchased from Sigma-Aldrich. Recombinant mouse Tnf- $\alpha$ and Jagged-2/Fc chimeric protein were purchased from R\&D Systems.

Histology and immunofluorescence. Histological analysis of pancreases was carried out by standard procedures. Specimens were harvested from timematched animals, fixed in buffered formalin, and embedded in paraffin. Tissue sections $(5 \mu \mathrm{m})$ were stained with hematoxylin and eosin or used for immunostaining. PanIN lesions and PDACs were graded as previously described (56). Proliferating cells were assessed by immunohistochemistry using an anti-PCNA antibody (BD Biosciences). Trichrome (Masson's) staining was carried out according to the manufacturer's instructions (Sigma-Aldrich). For immunofluorescence staining, cells were stained using anti-Hes1 (Santa Cruz Biotechnology Inc.) or anti-E-cadherin (Invitrogen) primary antibodies. Cell nuclei were counterstained with DAPI, and cells were visualized under a LSM 510 confocal microscope.

Flow cytometry. Pancreases were minced and digested with $2 \mathrm{mg} / \mathrm{ml}$ collagenase type IV (Sigma-Aldrich). Single-cell suspensions were prepared and cells were immunolabeled with fluorochrome-conjugated antibodies in PBS supplemented with 1\% FBS. All antibodies were purchased from eBioscience: anti-F4/80-APC (clone BM8), anti-CD11b-PE (M1/70), anti-Ly6G-FITC (RB6-8C5). Flow cytometric data were subsequently acquired on a FACSCalibur flow cytometer (BD Biosciences) and analyzed using FlowJo software. For sorting of Eyfp-positive pancreatic epithelial cells, single-cell suspensions were further digested with $0.05 \%$ trypsin (Sigma-Aldrich), and EYFP-positive cells were collected using a FACSAria II sorter (BD Biosciences).

Real-time PCR analysis, protein expression, and kinase activity assay. Total tissue RNA was prepared using an RNeasy kit (QIAGEN). Quantitative PCR was performed as described previously (57). We performed antibody-based multiplex cytokine arrays analyzing the abundance of 62 cytokines and chemokines (Millipore). Tnf- $\alpha$ levels in cell culture supernatants were determined using a commercially available ELISA kit (R\&D Systems) according to the manufacturer's instructions. Cells and tumors were lysed and analyzed by SDS-PAGE and immunoblotting (58) with antibodies to Hes1 and Rbp-j (both from Santa Cruz Biotechnology Inc.), Ikk2 (Cell Signaling Technology), and $\beta$-actin (Sigma-Aldrich). In vitro Ikk2 kinase activity was assessed using the Kinase Assay Kit (Cell Signaling Technology) according to the manufacturer's instructions.

ChIP. ChIP was performed with the EZ-ChIP Assay Kit (Millipore) in accordance with the manufacturer's instructions. A total of $10^{6}$ PanIN cells were used per condition. Antibodies against phospho-histone $\mathrm{H} 3$ at serine 10 (Cell Signaling Technology), anti-total histone H3 (Cell Signaling Technology), and control rabbit IgG (R\&D Systems) were used.

siRNA transfection. Rbpj-, Ikk2-, and Hes1-specific siRNAs and nontargeting control siRNAs were purchased from Dharmacon. siRNAs were transfected with Lipofectamine RNAiMAX reagent (Invitrogen).

Luciferase reporter assay. For Hes1 reporter gene assays, primary Kras ${ }^{G 12 D}$ $\mathrm{Tnfa}^{\Delta P d x}$ and $\mathrm{Kras}^{G 12 D} I k k 2^{\Delta P d x}$ cells were transfected in duplicate in 24-well plates with a Hes 1 luciferase reporter construct containing the -194 to +160 promoter fragment of the Hes 1 gene inserted upstream of the luciferase gene in pGL2 (gift from Sangram S. Sisodia, Department of Neurobiology, University of Chicago, Chicago, Illinois, USA) and an internal control plasmid encoding Renilla luciferase (Promega) with Lipofectamine Plus reagent from Invitrogen $(59,60)$. On the next day, cells were stimulated with rTnf- $\alpha$ for 6 hours, and cell lysates were prepared and analyzed for firefly and Renilla luciferase activity with the Dual-Luciferase Reporter Assay System 

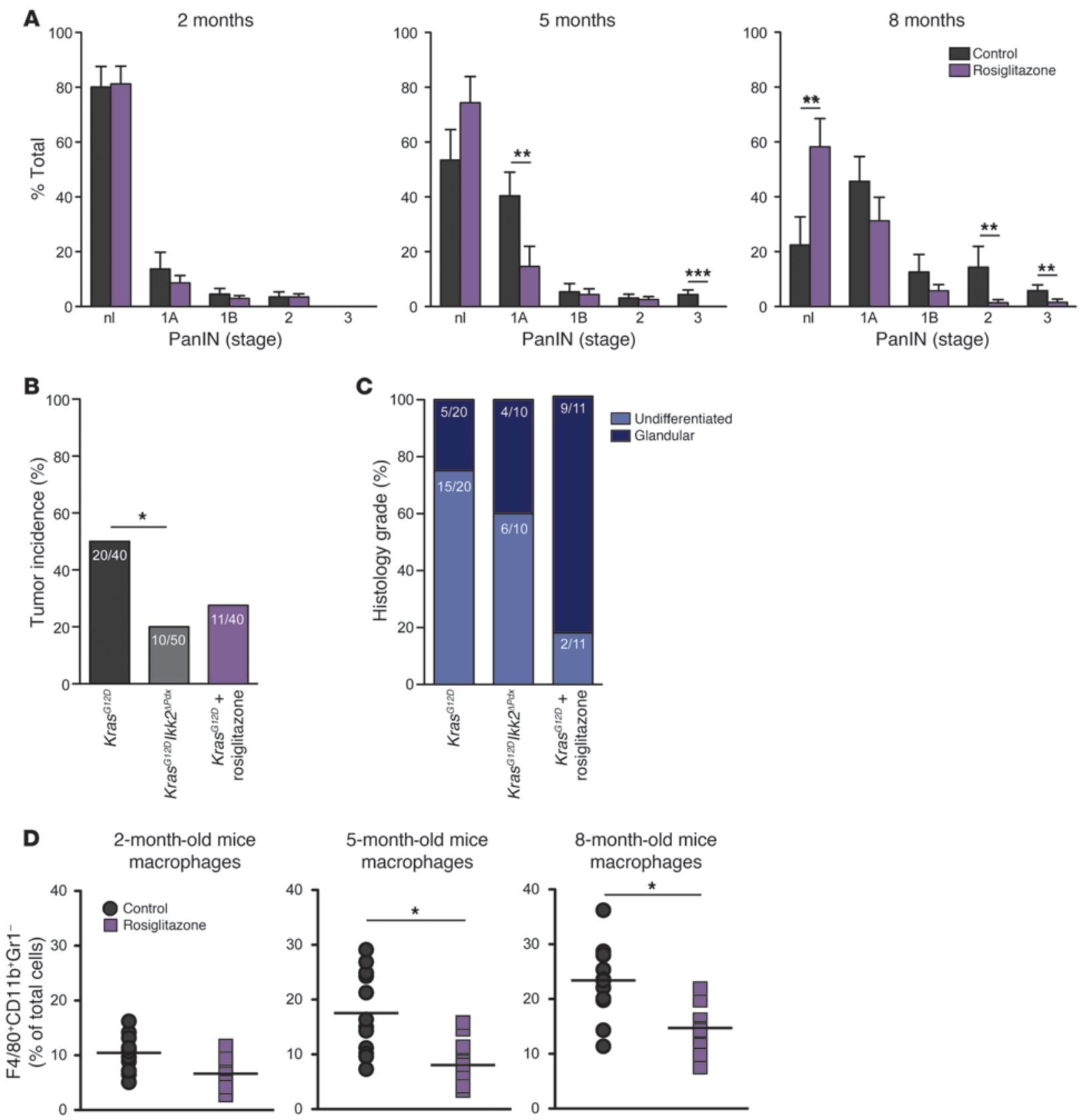

Figure 8

Rosiglitazone treatment blocks PanIN progression in Kras ${ }^{G 12 D}$ mice. (A) Quantification of the percentage or pancreatic parenchyma occupied by PanINs in Kras ${ }^{G 12 D}$ mice treated with rosiglitazone compared with untreated controls. Values are shown as mean $+\mathrm{SD} ; n=12$. (B) Tumor incidence and (C) histology grade in rosiglitazone-treated Kras ${ }^{G 12 D}$ mice compared with untreated $K$ ras $^{G 12 D}$ and $K$ ras $^{G 12 D} / k_{k} 2^{\Delta P d x}$ mice. (D) Percentage of $\mathrm{F} 4 / 80^{+} \mathrm{CD} 11 \mathrm{~b}^{+} \mathrm{Gr} 1^{-}$cells in the pancreas of 2-, 5-, and 8-month-old Kras ${ }^{G 12 D}$ mice treated with rosiglitazone or untreated as measured by flow cytometry. Each data point represents an individual mouse. Mean values are depicted by the horizontal lines; $n=10$. ${ }^{*} P<0.05,{ }^{* *} P<0.01,{ }^{* * *} P<0.001$.

(Promega). The Pparg reporter gene and Hes1 plasmids (gifts from Marc Montminy, Salk Institute for Biological Studies, La Jolla, California, USA) have been previously described (31). Cells were transfected with the Pparg reporter plasmids and an expression plasmid encoding Hes 1 or a control vector as described for Hes 1 reporter gene assays. Results are shown as firefly normalized to Renilla luciferase activity.

Statistics. Results were tested for statistical significance using 1- or 2-way ANOVA and Bonferonni's multiple comparisons test on GraphPad Prism version $4.0 \mathrm{c}$ software. Tumor incidence was analyzed by Fisher's exact test. $P$ values of 0.05 or less were considered statistically significant.

Study approval. Mice were maintained under specific pathogen-free conditions in the Biological Services Unit, Barts Cancer Institute, Queen Mary University of London, and used according to the established institutional guidelines under the authority of a UK Home Office project license (Guidance on Operation of Animals [Scientific Procedures] Act 1986; all animal studies were approved by the UK Home Office). 


\section{Acknowledgments}

This work is supported by the Medical Research Council (grant G0601867) and Cancer Research UK (grant C18270/A11251). F.R. Balkwill acknowledges the support of the Higher Education Funding Council for England. D.A. Tuveson acknowledges the support of the University of Cambridge, Cancer Research UK, and Hutchison Whampoa Limited. We thank Simon Hallam (Barts Cancer Institute, United Kingdom) for critical review of the manuscript.
Received for publication July 19, 2011, and accepted in revised form September 28, 2011.

Address correspondence to: Thorsten Hagemann, Centre for Cancer and Inflammation, Barts Cancer Institute, Queen Mary University of London, John Vane Science Centre, Charterhouse Square, London EC1M 6BQ, United Kingdom. Phone: 44.20.7882.3590; Fax: 44.20.7882.3885; E-mail: t.hagemann@qmul.ac.uk.
1. Mantovani A, Allavena P, Sica A, Balkwill F. Cancer-related inflammation. Nature. 2008; 454(7203):436-444.

2. Downward J. Targeting RAS signalling pathways in cancer therapy. Nat Rev Cancer. 2003;3(1):11-22.

3. Jaffee EM, Hruban RH, Canto M, Kern SE. Focus on pancreas cancer. Cancer Cell. 2002;2(1):25-28.

4. Hruban $\mathrm{RH}$, et al. Pancreatic intraepithelial neoplasia: a new nomenclature and classification system for pancreatic duct lesions. Am J Surg Pathol. 2001;25(5):579-586.

5. Hingorani SR, et al. Preinvasive and invasive ductal pancreatic cancer and its early detection in the mouse. Cancer Cell. 2003;4(6):437-450.

6. Guerra C, et al. Tumor induction by an endogenous K-ras oncogene is highly dependent on cellular context. Cancer Cell. 2003;4(2):111-120.

7. Meylan E, et al. Requirement for NF-kappaB signalling in a mouse model of lung adenocarcinoma. Nature. 2009;462(7269):104-107.

8. Bassères DS, Ebbs A, Levantini E, Baldwin AS. Requirement of the NF-kappaB subunit p65/RelA for K-Ras-induced lung tumorigenesis. Cancer Res. 2010;70(9):3537-3546.

9. Hagemann T, Biswas SK, Lawrence T, Sica A, Lewis CE. Regulation of macrophage function in tumors: the multifaceted role of NF-kappaB. Blood. 2009; 113(14):3139-3146.

10. Greten FR, et al. IKKbeta links inflammation and tumorigenesis in a mouse model of colitis-associated cancer. Cell. 2004;118(3):285-296.

11. Yang J, et al. Conditional ablation of Ikkb inhibits melanoma tumor development in mice. J Clin Invest. 2010;120(7):2563-2574.

12. Lu Z, et al. miR-301a as an NF-kappaB activator in pancreatic cancer cells. EMBO J. 2010;30(1):57-67.

13. Vilimas T, et al. Targeting the NF-kappaB signaling pathway in Notch1-induced T-cell leukemia. Nat Med. 2007;13(1):70-77.

14. Wu WK, et al. Dysregulation of cellular signaling in gastric cancer. Cancer Lett. 2010;295(2):144-153.

15. Miyamoto Y, et al. Notch mediates TGF alpha-induced changes in epithelial differentiation during pancreatic tumorigenesis. Cancer Cell. 2003;3(6):565-576.

16. Bray SJ. Notch signalling: a simple pathway becomes complex. Nat Rev Mol Cell Biol. 2006;7(9):678-689.

17. Mazur PK, et al. Notch2 is required for progression of pancreatic intraepithelial neoplasia and development of pancreatic ductal adenocarcinoma. Proc Natl Acad Sci U S A. 2010;107(30):13438-13443.

18. De La O JP, et al. Notch and Kras reprogram pancreatic acinar cells to ductal intraepithelial neoplasia. Proc Natl Acad Sci U S A. 2008;105(48):18907-18912.

19. Morris JP 4th, Cano DA, Sekine S, Wang SC, Hebrok $\mathrm{M}$. $\beta$-catenin blocks Kras-dependent reprogramming of acini into pancreatic cancer precursor lesions in mice. J Clin Invest. 2010;120(2):508-520.

20. Kulbe H, et al. The inflammatory cytokine tumor necrosis factor-alpha generates an autocrine tumorpromoting network in epithelial ovarian cancer cells. Cancer Res. 2007;67(2):585-592.

21. Plentz R, et al. Inhibition of gamma-secretase activity inhibits tumor progression in a mouse model of pancreatic ductal adenocarcinoma. Gastroenterology. 2009;136(5):1741-1749.

22. Bash J, et al. Rel/NF-kappaB can trigger the Notch signaling pathway by inducing the expression of Jagged1, a ligand for Notch receptors. EMBO J.
1999;18(10):2803-2811.

23. Amsen D, Blander JM, Lee GR, Tanigaki K, Honjo $\mathrm{T}$, Flavell RA. Instruction of distinct CD4 T helper cell fates by different notch ligands on antigen-presenting cells. Cell. 2004;117(4):515-526.

24. Fung E, et al. Delta-like 4 induces notch signaling in macrophages: implications for inflammation. Circulation. 2007;115(23):2948-2956

25. Monsalve E, et al. Notch-1 up-regulation and signaling following macrophage activation modulates gene expression patterns known to affect antigenpresenting capacity and cytotoxic activity. J Immunol. 2006;176(9):5362-5373.

26. Palaga $T$, et al. Notch signaling is activated by TLR stimulation and regulates macrophage functions. Eur J Immunol. 2008;38(1):174-183.

27. Gordon WR, Arnett KL, Blacklow SC. The molecular logic of Notch signaling - a structural and biochemical perspective. J Cell Sci. 2008; 121(pt 19):3109-3119.

28. Anest V, Hanson JL, Cogswell PC, Steinbrecher KA, Strahl BD, Baldwin AS. A nucleosomal function for IkappaB kinase-alpha in NF-kappaB-dependent gene expression. Nature. 2003;423(6940):659-663.

29. Saccani S, Natoli G. Dynamic changes in histone H3 Lys 9 methylation occurring at tightly regulated inducible inflammatory genes. Genes Dev. 2002;16(17):2219-2224.

30. Yamamoto Y, Verma UN, Prajapati S, Kwak YT, Gaynor RB. Histone H3 phosphorylation by IKKalpha is critical for cytokine-induced gene expression. Nature. 2003;423(6940):655-659.

31. Herzig S, Hedrick S, Morantte I, Koo SH, Galimi F, Montminy M. CREB controls hepatic lipid metabolism through nuclear hormone receptor PPARgamma. Nature. 2003;426(6963):190-193.

32. Fischer A, Gessler M. Delta-Notch - and then? Protein interactions and proposed modes of repression by Hes and Hey bHLH factors. Nucleic Acids Res. 2007;35(14):4583-4596.

33. Iso T, Kedes L, Hamamori Y. HES and HERP families: multiple effectors of the Notch signaling pathway. J Cell Physiol. 2003;194(3):237-255.

34. Tanigaki K, Honjo T. Regulation of lymphocyte development by Notch signaling. Nat Immunol. 2007;8(5):451-456.

35. Straus DS, Glass CK. Anti-inflammatory actions of PPAR ligands: new insights on cellular and molecular mechanisms. Trends Immunol. 2007;28(12):551-558.

36. Straus DS, et al. 15-deoxy-delta 12,14-prostaglandin $\mathrm{J} 2$ inhibits multiple steps in the NF-kappa B signaling pathway. Proc Natl Acad Sci U S A. 2000; 97(9):4844-4849.

37. Maeda S, Kamata H, Luo JL, Leffert H, Karin M. IKKbeta couples hepatocyte death to cytokine-driven compensatory proliferation that promotes chemical hepatocarcinogenesis. Cell. 2005;121(7):977-990.

38. Grivennikov SI, Greten FR, Karin M. Immunity, inflammation, and cancer. Cell. 2010;140(6):883-899.

39. Grivennikov SI, Karin M. Dangerous liaisons: STAT3 and NF-kappaB collaboration and crosstalk in cancer. Cytokine Growth Factor Rev. 2010;21(1):11-19.

40. Moore RJ, et al. Mice deficient in tumor necrosis factor-alpha are resistant to skin carcinogenesis. Nat Med. 1999;5(7):828-831.

41. Espinosa L, et al. The Notch/Hes1 pathway sustains NF-kappaB activation through CYLD repression in T cell leukemia. Cancer Cell. 2010;18(3):268-281.
42. Clark CE, Hingorani SR, Mick R, Combs C, Tuveson DA, Vonderheide RH. Dynamics of the immune reaction to pancreatic cancer from inception to invasion. Cancer Res. 2007;67(19):9518-9527.

43. Guerra C, et al. Chronic pancreatitis is essential for induction of pancreatic ductal adenocarcinoma by K-Ras oncogenes in adult mice. Cancer Cell. 2007; 11(3):291-302.

44. Khasawneh J, et al. Inflammation and mitochondrial fatty acid beta-oxidation link obesity to early tumor promotion. Proc Natl Acad Sci U S A. 2009; 106(9):3354-3359.

45. Siveke JT, Einwächter H, Sipos B, Lubeseder-Martellato C, Klöppel G, Schmid RM. Concomitant pancreatic activation of $\operatorname{Kras}(\mathrm{G} 12 \mathrm{D})$ and Tgfa results in cystic papillary neoplasms reminiscent of human IPMN. Cancer Cell. 2007;12(3):266-279.

46. Glass CK, Saijo K. Nuclear receptor transrepression pathways that regulate inflammation in macrophages and T cells. Nat Rev Immunol. 2010;10(5):365-376.

47. Zoete V, Grosdidier A, Michielin O. Peroxisome proliferator-activated receptor structures: ligand specificity, molecular switch and interactions with regulators. Biochim Biophys Acta. 2007;1771(8):915-925.

48. Kota BP, Huang TH, Roufogalis BD. An overview on biological mechanisms of PPARs. Pharmacol Res. 2005;51(2):85-94

49. Currie CJ, Poole CD, Gale EA. The influence of glucose-lowering therapies on cancer risk in type 2 diabetes. Diabetologia. 2009;52(9):1766-1777.

50. Evans JM, Donnelly LA, Emslie-Smith AM, Alessi DR, Morris AD. Metformin and reduced risk of cancer in diabetic patients. BMJ. 2005;330(7503):1304-1305.

51. Grivennikov SI, et al. Distinct and nonredundant in vivo functions of TNF produced by $\mathrm{T}$ cells and macrophages/neutrophils: protective and deleterious effects. Immunity. 2005;22(1):93-104.

52. Fong $\mathrm{CH}$, et al. An antiinflammatory role for IKKbeta through the inhibition of "classical" macrophage activation. J Exp Med. 2008;205(6):1269-1276.

53. Kühn R, Schwenk F, Aguet M, Rajewsky K. Inducible gene targeting in mice. Science. 1995; 269(5229):1427-1429

54. Schreiber FS, et al. Successful growth and characterization of mouse pancreatic ductal cells: functional properties of the Ki-RAS(G12V) oncogene. Gastroenterology. 2004;127(1):250-260.

55. Taghon TN, David ES, Zúñiga-Pflücker JC, Rothenberg EV. Delayed, asynchronous, and reversible T-lineage specification induced by Notch/Delta signaling. Genes Dev. 2005;19(8):965-978.

56 . Hruban RH, et al. Pathology of genetically engineered mouse models of pancreatic exocrine cancer: consensus report and recommendations. Cancer Res. 2006;66(1):95-106.

57. Charles KA, et al. The tumor-promoting actions of TNF- $\alpha$ involve TNFR1 and IL-17 in ovarian cancer in mice and humans. J Clin Invest. 2009; 119(10):3011-3023.

58. Hagemann T, et al. "Re-educating" tumor-associated macrophages by targeting NF-kappaB.J Exp Med. 2008;205(6):1261-1268.

59. Jarriault S, Brou C, Logeat F, Schroeter EH, Kopan R, Israel A. Signalling downstream of activated mammalian Notch. Nature. 1995;377(6547):355-358.

60. Berechid BE, Thinakaran G, Wong PC, Sisodia SS, Nye JS. Lack of requirement for presenilin1 in Notch1 signaling. Curr Biol. 1999;9(24):1493-1496. 